\title{
Cemeteries as (un)wanted heritage of previous communities. An example of changes in the management of cemeteries and their social perception in Gdańsk, Poland
}

\begin{abstract}
Cemeteries, despite the sacred values attributed to them, proving their inviolability and durability, undergo functional transformations in the dynamic structure of developing cities. This article focuses on the city of Gdańsk, which historically changed its statehood several times. Almost a full exchange of population from German to Polish took place after World War II. The main aim of the article is to compare the post-1945 attitudes of the new Gdańsk community and the authorities towards cemeteries being a legacy of their predecessors. During World War II and the three subsequent decades most of the unwanted (unrelated to the Polish community) necropolises were closed down and removed. 25 of the 101 inventoried cemeteries have survived until modern times. It has been shown that there are clear differences in the management of cemeteries after 1945, from the removing them in the communist times to the commemorating and revitalizing them during the maturing democracy. This is associated with the current social views, where the majority of residents object to changing the function of the sites of the former cemeteries and only allow converting them into greenery with commemoration of the history of the place.
\end{abstract}

Krystian Puzdrakiewicz ${ }^{1 *}$

1) University of Gdańsk, Institute of Geography, Regional Development Division, Gdańsk, Poland

*Corresponding author: Krystian Puzdrakiewicz, University of Gdańsk, Institute of Geography, Regional Development Division, J. Bażyńskiego street no. 4; 80-309 Gdańsk, Poland; E-mail: krystian. puzdrakiewicz@ug.edu.pl

\section{Keywords:}

cemeteries; former cemetery areas; land use transformation; social perception; Gdańsk; Poland 


\section{Introduction}

\subsection{Justification background and goals of the study}

Existence of burial places is necessary for proper functioning of urban areas even if only for sanitary reasons (Ashton, 2019; Neckel et al., 2017). Becoming a burial site, an area gains intangible values connected with the sacrum. Closing or even removing a cemetery does not deprive it of this asset, which may affect the way such land transformations are perceived. Przybylska (2014) provided a detailed literature review proving that cemeteries are key elements when analysing the essence of sacred space (sacrum). Lewicka (2017) states that necropolises have a symbolic and significant meaning for the whole community whose relatives are buried in a particular place, regardless of the community's religiousness. For this reason, transformations in the use of areas that are ascribed religious, cultural or identity values are a vital research subject.

It is increasingly common for developing cities to face the problem of lack of free space for new infrastructural projects and the necessity to reconcile interests of different stakeholders. Therefore, city authorities often turn to cemeteries, as necessary yet problematic spaces. In the public discourse, there are different views on the future of cemeteries located in densely built-up urban areas. One of the issues is whether it is morally appropriate to dedicate large spaces to the dead when the living struggle for proper living conditions (Allam, 2019). Competition for urban space between the living and the dead, called spatial competition, makes it difficult to designate new areas as burial sites (Neckel et al., 2017; Kong, 2012). Cemeteries are usually perceived as cumbersome and unwanted neighbourhood. However, they play a fundamental urban function, which is a classic example of the NIMBY (not-in-my-back-yard) syndrome (Davies \& Bennett, 2016; Tudor et al., 2013). Being perceived so divergently - as sacred places or places for public use, they are exceptional venues in the functional-spatial structure of cities. Public perception may affect the quality of transformed spaces and it is currently becoming a significant factor when designing landscape of modern cemeteries
(Długozima \& Rej, 2014; Wingren, 2013). Vast green areas within a cemetery space increase their social acceptance. It is also a way of implementing the idea of sustainable development in the process of urban planning. Moreover, physical and geographical conditions of an area declared for the burial purposes are of great importance in the context of their safe and sustainable usage (Al-Akl et al., 2018; Tudor et al., 2013; Uslu et al., 2009). The same applies to the areas of former cemeteries, which play an environmental and social role in the urban structure (Uslu, 2010). Access to cemeteries is granted to people with various expectations and requirements, which triggers problems in defining the rules of public use of these areas (Woodthorpe, 2011). Adapting the ways of developing necropolises to the modern standards as well as making it possible to introduce new burial practices shall meet current needs of societies. Cemeteries will become open spaces, which contradicts the deeply rooted influence of the Roman-Catholic Church in Central Europe (Folíková Palánová \& Juračka, 2018). In the nearby Scandinavian countries, cemeteries are assigned recreational functions and they are places for every-day activities e.g. jogging, hiking, walking dogs, etc. (Grabalov, 2018; Nordh \& Evensen, 2018). In Poland, it is rare for people to visit cemeteries for purposes other than visiting graves of their loved ones.

During the process of urban development, a city not only sprawls, but some internal functional-spatial changes also take place. Sometimes, the changes may be drastic, like in the event of a war. They may be of cultural, social or political nature. In the case of Gdańsk, after the end of World War II, there was an exchange of the population from German to Polish, whose consequences can be identified, among others, in the social and physical changes in the urban fabric. The development of local identity in places with broken historical continuity is difficult and can take many forms. This can also be influenced by the existing political system. In the post-war years, Poland was ruled under the communist system, and since 1989, there has been democracy with self-government exercising real power. The main objective of the article is to compare the post-1945 attitudes of the new Gdańsk community and the authorities representing it towards cemeteries being a legacy of their predecessors. These attitudes are primari- 
ly understood as a set of actions that embody the dominant views of society and/or authorities. Five specific objectives have been formulated for this main objective:

1. Classification of Gdańsk cemeteries throughout the city's existence;

2. Identification and reconstruction of the processes and the causes of establishing and removing cemeteries throughout the city's history;

3. Identification and classification of the current actual use of post-cemetery sites;

4. Identification of the current spatial policy on cemeteries;

5. Assessment of the social perception of removing and functional transformation of the former and the present cemeteries among the contemporary population of Gdańsk.

\subsection{Basic concepts}

The term "cemetery" is generally perceived as simple and common. Usually, it refers to an area where human remains are buried in single and mass graves or in a columbarium. An English word "cemetery", French "cimetière" or Polish "cmentarz" all derive from a Latin word "coemeterium" (in Gr. "koimeterion" - the place where we sleep), meaning the place where the dead are buried or the resting place. In German, terms "Kirchof" (literally "churchyard") or "Friedhof" ("a peaceful place") were used. The term "necropolis" (in Gr. "the city of the dead") refers to a medieval or early Christian cemetery yet, since the

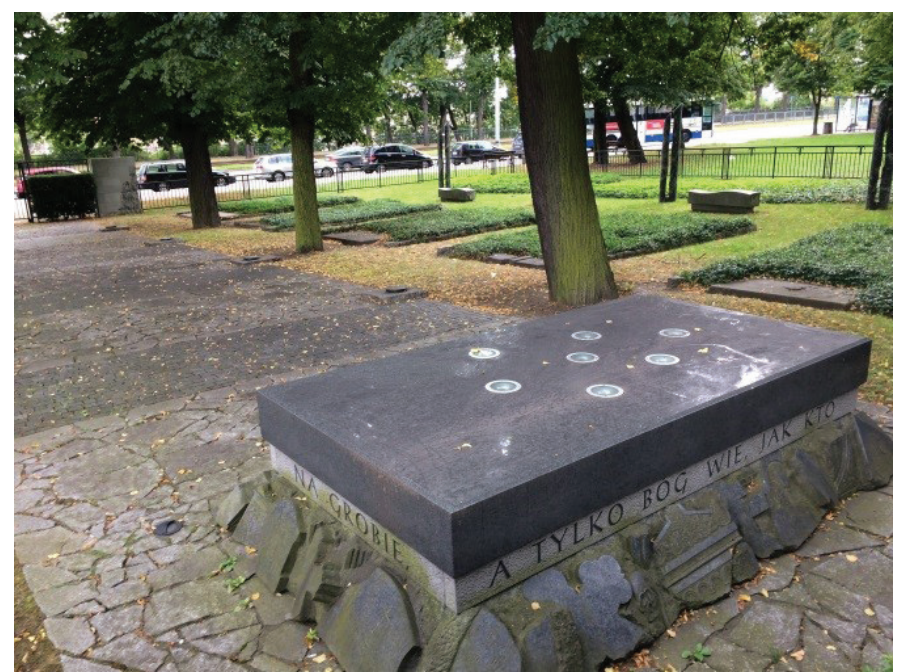

Figure 1. Cemetery of Non-existed Cemeteries - a monument in place of the former Cmentarz Bożego Ciała i Lazaretu [Corpus Christi and Lazaret Cemetery]. Photo: K. Puzdrakiewicz. $19^{\text {th }}$ century, it has been used as a synonym for the word "cemetery" (Janicki, 2014; Tisler \& Turzyński, 2012; Urbain, 2011).

Polish law does not directly define the term "cemetery". However, the Act of 31 January 1959 on Cemeteries and Burial of the Deceased (Journal of Laws Dz.U. from 2019, No. 1473, item 1473) specifies that it must be a fenced area, meeting sanitary standards, established or enlarged with the respect to the local spatial development plan. However, actual state of a particular estate does not have to reflect its legal status or values assigned to it by society. Tenenbaum-Kulig (2015) describes interpretation difficulties when analysing the Act on Cemeteries and Burial of the Deceased, especially the following undefined terms: a cemetery, a cemetery area, a post-cemetery area. She also claims such situation largely affects court decisions. In the literature, a cemetery is usually broadly defined with no references to any specific law system. For instance, Rugg (2000, p. 264) defines cemeteries as "specifically demarcated sites of burial, with internal layout that is sufficiently well ordered to allow families to claim and exercise control over the particular grave space, and which facilitate the conducting of appropriate funerary ritual". Kolbuszewski (1996) defines a cemetery as an institutionally established area with a programmed burial function, organised according to particular culturally determined directives, with observance to the existing historically grounded burial and commemorating traditions. According to the Central Statistical

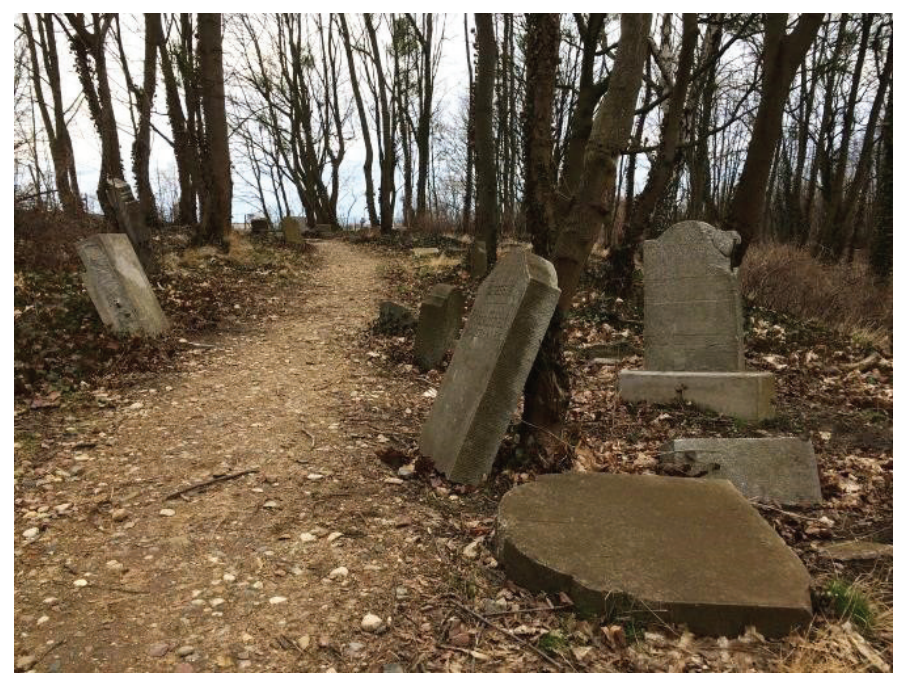

Figure 2. Nostalgic Park - a monument in place of the former urn cemetery in Traugutta Street (so-called forest cemetery). Photo: K. Puzdrakiewicz. 
Office (2019) in Poland, a cemetery is a place with green landscape elements where the dead (humans or animals) are buried, regardless of its legal status, ownership or area covered. Rudkowski (2004) and Pasierb (1995) states that each cemetery is composed of three basic elements: graves (with coffins inside), ground structures and different landscape objects (monuments, chapels, paths) and cemetery plants. However, this classification does not mention a columbarium as an alternative form of burial. It does not have a formal character though and it only describes the actual state, not taking the legal status of a given area into consideration. For the purposes of this article, the author adopted the definition by Kolbuszewski, adding cemeteries in the form of monuments with no burial function.

Symbolic cemeteries in the form of monuments are places physically reflecting the idea of a burial site. They may be empty graves or places not being burial sites but symbolically evoking some ideological values (Gajewska, 2011). In Gdańsk there are two such objects: Cemetery of Non-existent Cemeteries established in 2002 (Figure 1) and a forest cemetery where in 2018 Nostalgic Park was organised (Figure 2). Both of the above-mentioned sites are located in post-cemetery areas, so they have some sacred values. Yet, they are not burial sites any more. That is why they were classified as inactive cemeteries. They are significant objects in historical and identity contexts.

\subsection{Cemeteries in Poland}

Cemeteries constitute an inherent part of social spaces. They play an important role in the structure of urban areas, yet they are not a common subject of scientific consideration or research, especially in the context of functional and spatial transformations. In Poland, the issue of historical or cultural values of former cemeteries had not been investigated until the period of World War II (Rudkowski, 2004). Mostly in the last decade, an increasing interest in necropolises has been observed, which results from ongoing urbanisation processes and spatial pressure but also from migration and cultural diffusion (Majewska, 2020; Majewska et al., 2019; Pilarczyk, 2019; Majewska, 2017; Długozima, 2011; Rydzewska et al., 2011; Żurkowska, 2009; Holly, 2007; Knercer 1995).
The existing studies in Poland usually focus on cemetery infrastructure in the context of landscape or architecture, burial practices, famous people buried in particular places, historical reconstruction of establishing or removing cemeteries (however, they usually lack analyses of the further history of these areas). There are also monographs on particular cemeteries, e.g. there are two interesting publications concerning cemeteries in Gdańsk by Krüger (2016, on the garrison cemetery) and Jażdżewski (2012, concerning the Zaspa cemetery). It is worth noting that in 1995, an international conference "Cemetery Art" was organized in Poland and there was a Centre for the Preservation of Historic Landscape, dealing with the research of cemeteries. Interest in and care for cemeteries developed after the political transformation in Poland in 1989 and still continues.

Generally, Kubiak (2018) identified two types of cemeteries in Poland: civilised necropolises (relatives of the dead look after the graves) and forgotten and unwanted ones (abandoned necropolises), where natural succession usually takes place, and the graves are destroyed by the nature itself or by hooligans. The latter type comprises, among others, Old Jewish or German cemeteries often located in forests, and they are not only gradually disappearing from the face of the Earth, but also from human awareness. Nonetheless, an increased interest in old necropolises has been observed recently. Some associations and informal groups taking care and restoring old cemeteries have been established lately (Zawiła, 2019). This can be related to the emerging civil society, which is an element of maturing democracy.

Cemeteries reflect culture and they are meaningful sources of information concerning societies. Although burial areas are not subject to dynamic spatial transformations, they do reflect long-term changes in the approach to the dead, burial methods and commemorating dead people (Kolnberger, 2018; McClymont, 2018; Francis, 2003). Beside the material forms of commemorating the dead (e.g. gravestones, columbaria), the treatment of bodies is worth looking into. Changes in burial practices, modern customs or anticipating future trends are also very important issues from the social point of view (Rugg \& Parsons, 2018; Krupar, 2017; Klaufus, 
2014; Kong, 2012). According to traditional beliefs of the 19th-20th centuries, burial sites concentrated magical powers and were inviolable (Kość-Ryżko, 2011). The fact that Poles are very religious people is noteworthy. The results of a survey conducted by the Central Statistical Office in 2018 show that $80.7 \%$ of the Poles are believers and $93.5 \%$ declare belonging to a denomination (only 3.1\% declare being atheists). Nowadays Polish society still considers cemeteries as fixtures in time and space. Changes in burial practises and forms of commemorating the dead seem unlikely in the near future, maybe except for the growing rate of post-cremation interments (Lewicka, 2017). As Długozima (2011) states, in Poland there are significant differences between burial practices in urban and rural areas. In villages, traditional burials still prevail, while among the secular urban society cremation has become more common. The same patterns are observed globally. Cremation is considered a hygienic and land-saving burial option, which is extremely important in large cities (Stępa, 1993).

Communal cemeteries play a very important social role, especially in the context of multiculturalism. They promote religious tolerance through emotional empathy. They represent diversity among the dead, yet they are also spaces where people from different cultures meet when visiting graves of their relatives (Swensen \& Skår, 2019). Cemeteries, especially the historic ones, having extraordinary aesthetic values, are usually perceived as tourist attractions and are important for educational and empirical reasons (Tomašević, 2018; Young \& Light, 2016; Tanaś, 2004).

\subsection{Social research on the perception of cemeteries}

In studies concerning cemeteries, researchers tend to use surveys, interviews and behavioural observations. They may be useful when identifying multidimensional relations between society and cemeteries. The first Polish study on perception of particular elements of a city, including cemeteries, with the use of in-depth surveys was by Libura (1990). The author of this study noticed that people reluctantly talk, and even think, about death. Yet, they feel a strong emotional bond with cemeteries as resting places for their relatives, especially the elderly. Tanaś
(2004) carried out a survey concerning the perception of cemeteries in the context of their tourist attractiveness. Polish researchers have been paying more attention to this issue recently. Skórzyńska and Wachowiak (2016) studied how students perceive "non-existing cemeteries" in Gdańsk and Wrocław as monuments of the German past of both cities. Lewicka (2017) analysed the present importance of cemeteries to the citizens of Katowice. In turn, Zawiła (2019) carried out numerous interviews among activists acting for the benefit of cemeteries in order to analyse the process of inheriting them in the areas where forced mass migration movements took place, including Gdańsk. Among the examples of foreign studies: there are works by Lai et al. (2019), Evensen et al. (2017) and Swensen et al. (2016) who investigated how cemeteries are used by local communities in Scotland and Norway; by Nordh et al. (2017) focusing on cemeteries as spaces of mind and body regeneration; by Al-Akl et al. (2018) who studied social perception of cemeteries in Beirut as well as by Tudor et al. (2013) examining the relationship between cemeteries and residential areas in Bucharest. This type of research conducted by planners regardless of location can contribute to counteracting potential spatial conflicts in the event of changes in the use of a given area.

\section{Research scope}

Gdańsk is a city located in northern Poland lying on Gdańsk Bay, part of the Baltic Sea. Along with Sopot and Gdynia, it forms Tricity conurbation, which is one of the most attractive and fastest-developing urban areas in Poland. Tricity has a population of 753 thousand people, 471 thousand of whom live in the city of Gdańsk (on $31^{\text {st }}$ December 2019) (Local Data Bank, 2020). The first references to Gdańsk date back to the year of 997 . The city has a rich history with many bloody periods, which have marked the space of the city centre. The research area of this study covers the city of Gdańsk in its administrative boundaries, established in 2018. Most of the city's history is associated with the present area of Śródmieście [Downtown], and it can be traced back to the early $18^{\text {th }}$ century. Along with the city sprawl, 


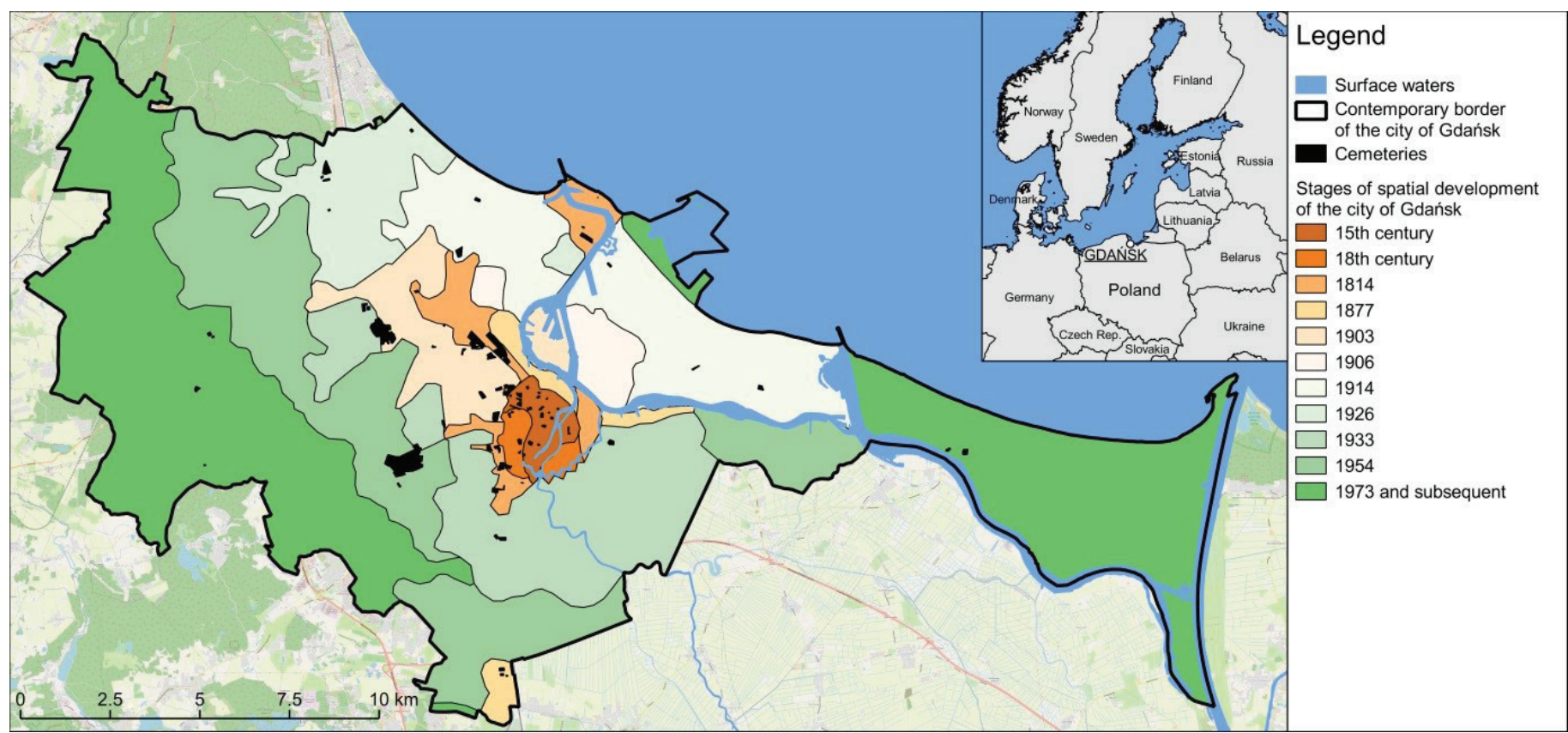

Figure 3. Spatial development of Gdańsk and location of cemeteries within the city historical and contemporary boundaries. Source: Own elaboration based on Labenz (1999), changed.

neighbouring settlements and their cemeteries were incorporated into Gdańsk (Figure 3). Eleven main stages of the spatial development can be distinguished, yet the most dynamic changes took place in the $20^{\text {th }}$ century. Obviously, spatial development involved cultural, social and political changes. The new circumstances influenced spatial policies, which, to some extent, reflected the social perception of cemeteries where people of different cultures and nation- alities had been buried (Figure 4). The statehood of the city changed fifteen times during its 1000-yearold history. Before it became Polish, among others, Gdańsk had been part of the Kingdom of Poland and of the German Empire. It had also been an autonomous territory named the Free City of Danzig. This historically established multiculturalism of Gdańsk was the main reason why the author selected it as the research area.

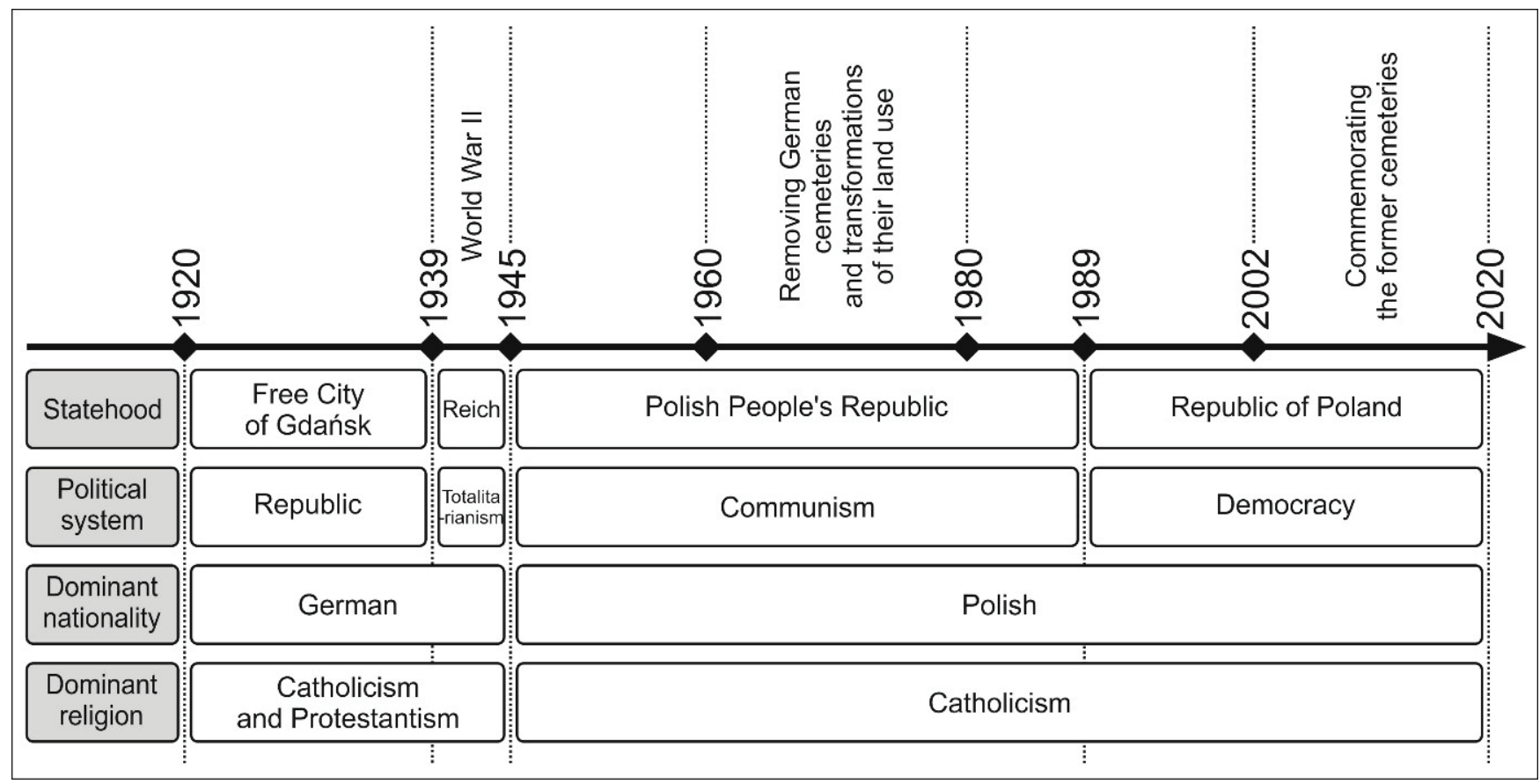

Figure 4. Social and political changes in Gdansk in the last 100 years. 


Specific objectives
Classification of Gdańsk cemeteries
throughout the city's existence

Figure 5. Research process flowchart.

\section{Methodological approach}

The structure of the article reflects the adopted research procedure consisting of five phases corresponding to the specific objectives (Figure 5).

The first part of the article (phases 1-2) is retrospective in character and is based on results of historical research and various sources, both literature, cartographic and online ones. The most important cartographic materials are German maps, including Plan der Stadt und Situation von Danzig (1711), Plan von der Gegend um Danzig (1807), Plan der Stadt Danzig (1920), Messtischblätter series (1910-1944) and others (Archiwalne Mapy Pomorza Gdańskiego, 2019). The Internet sources are useful when gathering data on cemeteries as some key information is published in a form of an encyclopaedic entry and can be found on portals dedicated to the history of a city or region (e.g. Gedanopedia, 2019 - online encyclopaedia of Gdańsk). An essential expert publication was the study by Labenz (1999) entitled Gdańsk Cemeteries. History and Conservation. The history of burial sites development in Gdańsk including chronology, location and religious affiliation. Unfortunately, a full publication is not available. In the study, the author listed 94 cemeteries. Now, it has been updated and seven additional sites have been added. The inventory concerning cemeteries as objects of research is still incomplete, especially when it comes to the oldest ones. Yet, some new facts are still being revealed by archaeologists.

In order to delimit the total area covered by burial sites in Gdańsk, cartographic materials from various periods were analysed, always taking the maximum size of a given cemetery into consideration. QGIS Georeferencer tool was used in order to determine the exact location of the sites. The cartographic materials were vectorised and particular objects were assigned attributes (analysis sheet) allowing their visualisation in the next step. In order to simplify the spatial and qualitative data, polygon objects were replaced by symbols. Different sizes of the symbols reflect actual areas covered by the analysed cemeteries and they are based on their centroids. All the analysed changes, both functional and spatial, concerning present and old cemeteries are based on planning documents, cartographic materials (including digital maps) and data collected during fieldwork. In order to determine current spatial functions of the cemetery and post-cemetery areas in Gdańsk, the author analysed a vector map being part of the study on conditions and spatial development directions, obtained from the Gdańsk Development Office. Additionally, some fieldwork research was done between May and August 2019.

In the period of April - September 2019, the author carried out a survey among the adult citizens of Gdańsk (older than 18, as the topic itself is complex and demands some maturity from the respondents) 
in order to determine how they perceive removal of old cemeteries or functional changes taking place in these areas. The survey consists of four closed questions and a personal data questionnaire (gender, age, education). They were distributed manually and online. In total, 429 complete surveys were collected and analysed. This number reaches data saturation as at the end of the research period the answers given by the respondents were not differentiated and they did not significantly change the final outcome. 27 questionnaires (5.9\% of all collected) were rejected, as they were incomplete or incorrectly filled in (multiple choices).

\section{Results}

\subsection{Systematisation of cemeteries}

Taking the entire history of Gdańsk into consideration, the author identified 101 cemeteries located within the city boundaries (it is a total number of identified cemeteries and due to the lack of data not all of them are analysed in the study). This study does not cover one animal cemetery established in 2016; it focuses only on human burial sites. At present, there are 25 cemeteries in the city, covering 112.88 ha, which constitutes $0.43 \%$ of the total area of the city. In total ( $\Sigma=95)$, the cemeteries cover an area of 177.90 ha $(0.68 \%$ respectively). A detailed location and area covered by two cemeteries were impossible to establish. Moreover, four cemeteries in Gdańsk Oliwa (Katolicki I [Catholic I], Katolicki II [Catholic II], Ewangelicki I [Lutheran I], Ewangelicki II [Lutheran II] have been closed and merged into one Cmentarz Komunalny [Communal Cemetery]. That is why the area they had covered was not added to the total area of Gdańsk cemeteries, as it equals the area of the contemporary communal cemetery.

Cemeteries can be classified according to their status, function, religious affiliation, location, etc. The Central Statistical Office defines the status of existing cemeteries, but does not collect data on this, nor does it collect data on the type of cemeteries. Active cemeteries are sites where human corpses or remains are buried in the ground, tombs or columbaria. Inactive ones are burial sites for which a closing down decision has been issued or a decision changing its function (Central Statistical Office as cited by Tanaś, 2004). The reason behind the closing down decision may be lack of burial places, which makes it impossible to bury the next deceased. In the history of Gdańsk, there were 101 cemeteries, 25 of them have remained until today. There are 16 active (including 7 with columbaria) and 9 inactive ones among them (Figure 6). Parish and monastery

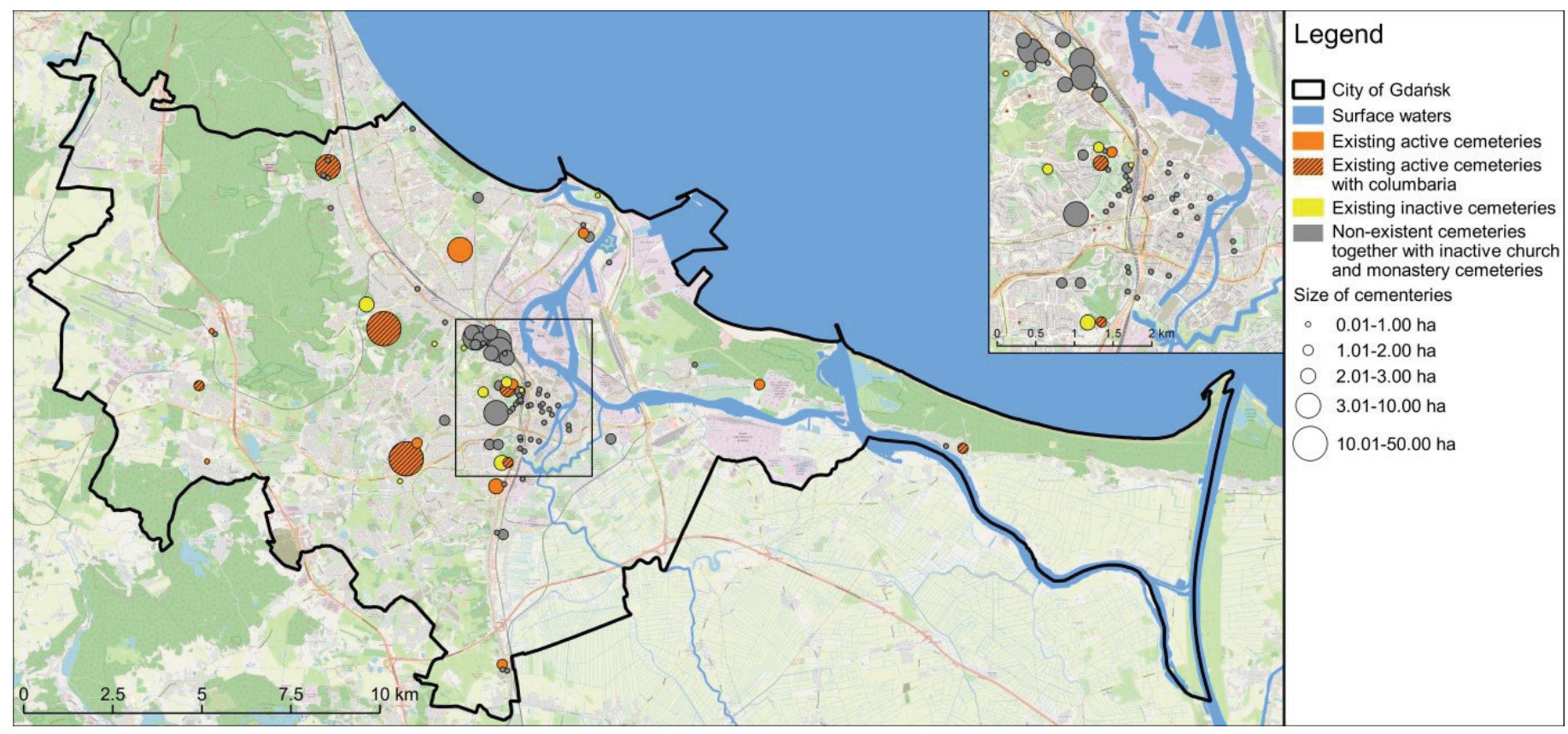

Figure 6. Cemeteries by their status. Source: Own elaboration based on Labenz (1999), changed. 


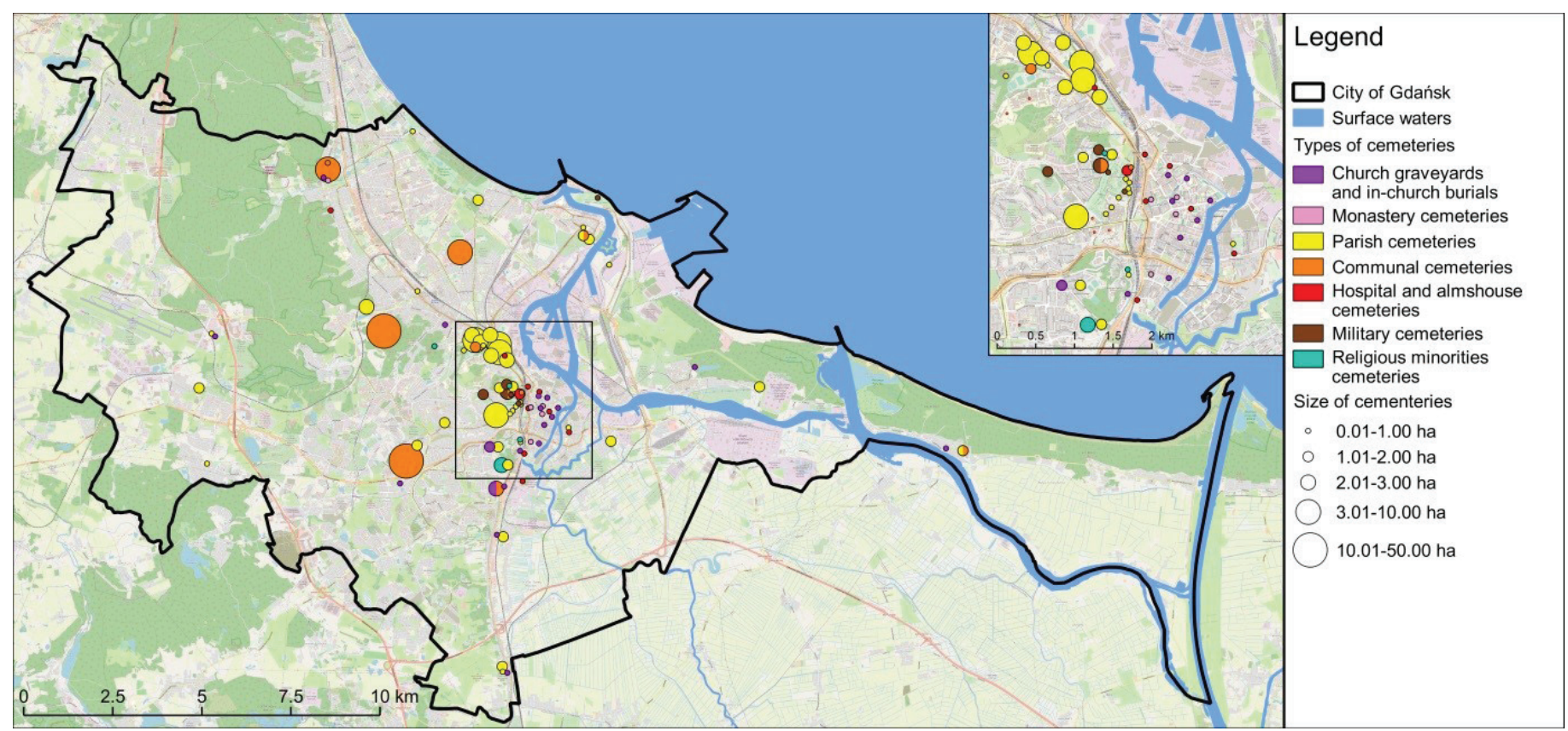

Figure 7. Cemeteries according to their type. Source: Own elaboration based on Labenz (1999), changed.

cemeteries are considered inactive as they do not serve as burial sites at present. However, the last burial taking place inside a church was in 2019 when an urn with remains of the former city mayor, Pawet Adamowicz, was buried in the most important basilica in Gdańsk.

Another classification may be created on the basis of cemetery types (their dominating character) (Figure 7). The following types can be found in Gdańsk ( $\Sigma=102$, comment: Garrison Cemetery was historically a military one. Nowadays, it is a communal cemetery. Therefore, it was assigned to two categories): parish cemeteries (45\%), church graveyards and inchurch burials (20\%), hospital and almshouse cemeteries $(12 \%)$, communal cemeteries $(8 \%)$, military cemeteries (6\%), monastery cemeteries (5\%) and religious minority cemeteries (4\%). Particularly noteworthy are the military and religious minority ones. The first type is a result of military operations causing death of numerous soldiers. They may be standalone burial sites with single or mass graves or they may be only part of a larger cemetery. There are six military cemeteries in Gdańsk: Wojskowy Cmentarz Francuski [French Military Cemetery], Żołnierzy Radzieckich [Russian Soldiers' Cemetery], Rosyjski [Russian Cemetery], Poległych za Ojczyznę [Soldiers Fighting for their Homeland], Poległych Obrońców Westerplatte [Soldiers fighting in Westerplatte] and
Garnizonowy [Garrison Cemetery]. As for the religious minority cemeteries, there are only four: two Jewish cemeteries, Mennonite cemetery and Atheist one.

Until the end of the World War II, Gdańsk had been inhabited by Polish and German citizens, and religious affiliation of the cemeteries reflects this (Figure 8). There were many Catholic, Protestant and mixed religious affiliation cemeteries at that time. After the war and emigration of the German population, only Roman Catholic parish cemeteries or communal ones with no religious affiliation were established. The structure of the cemeteries is as follows ( $\Sigma=104$, comment: Three cemeteries were assigned a double status, now communal and religious minority or military cemeteries in the past): Roman Catholic cemeteries (29\%), Protestant cemeteries (24\%), mixed Roman Catholic and Protestant cemeteries (22\%), communal cemeteries (12\%), military cemeteries (8\%), religious minorities cemeteries (4\%) and one not established cemetery (1\%). Although they may seem similar (because of their religious diversity), military cemeteries and communal ones cannot be counted as one category. Soldiers were buried only in selected areas (cemeteries or quarters) and military cemeteries are subjects to a separate legal framework. 


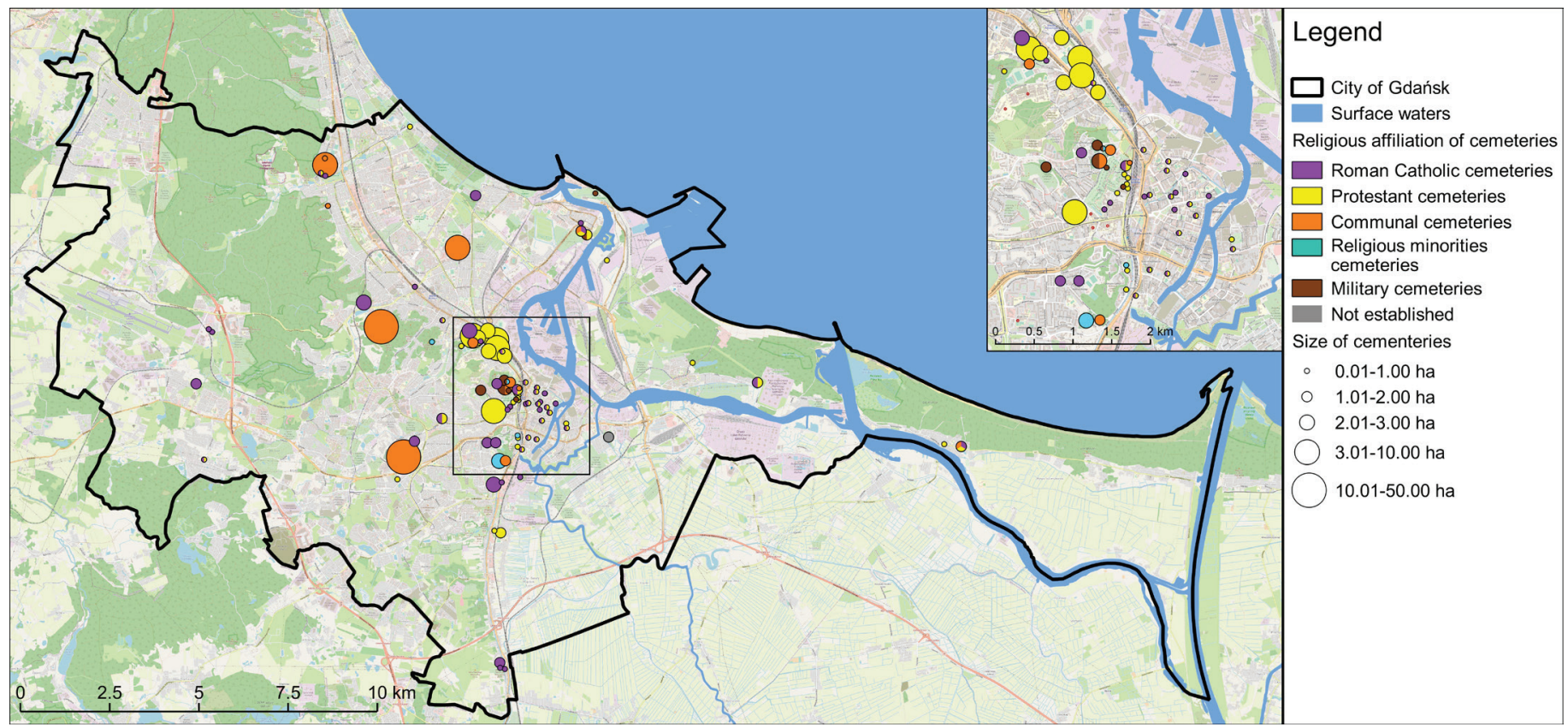

Figure 8. Cemeteries according to their religious affiliation. Source: Own elaboration based on Labenz (1999), changed.

In the Jewish tradition, burial sites are sacred and inviolable. Therefore, exhumation of bodies, removal of single graves or entire cemeteries are forbidden (Swensen, 2018; Borzyszkowska-Szewczyk, 2011). There are two such burial sites in Gdańsk. One of them is an inactive Jewish cemetery, which has been listed in the register of historical monuments (Figure 9). The other one is located in woods and only few objects have remained until today: some stairs, several destroyed graves and tombstones with Hebrew inscriptions (Figure 10). Unfortunately, this burial site is devastated to the extent making it difficult to recognise as a cemetery for ordinary people. How- ever, in the context of intangible values, both Jewish cemeteries are classified as existing yet inactive religious minority cemeteries. A similar fate is shared by a Jewish cemetery in Kaliningrad (Russia), which has been dilapidating since the World War II (Swensen, 2018).

The above-mentioned historical characteristics of Gdańsk cemeteries indicate that they were very diverse in the past. Nowadays, there are mostly communal cemeteries and Catholic burial sites in Gdańsk.

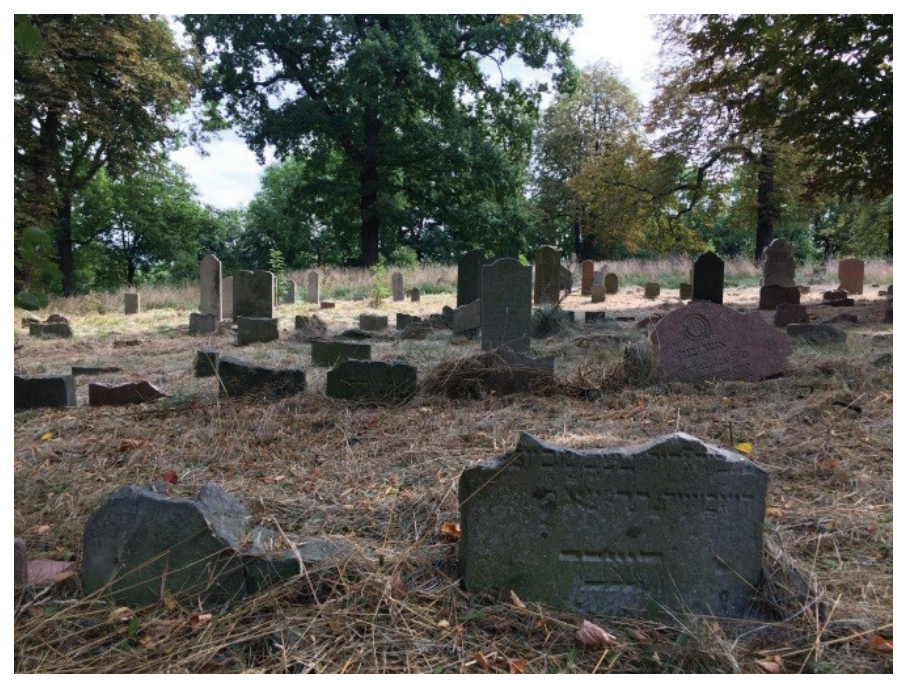

Figure 9: Jewish cemetery listed in the register of historical monuments. Photo: K. Puzdrakiewicz.

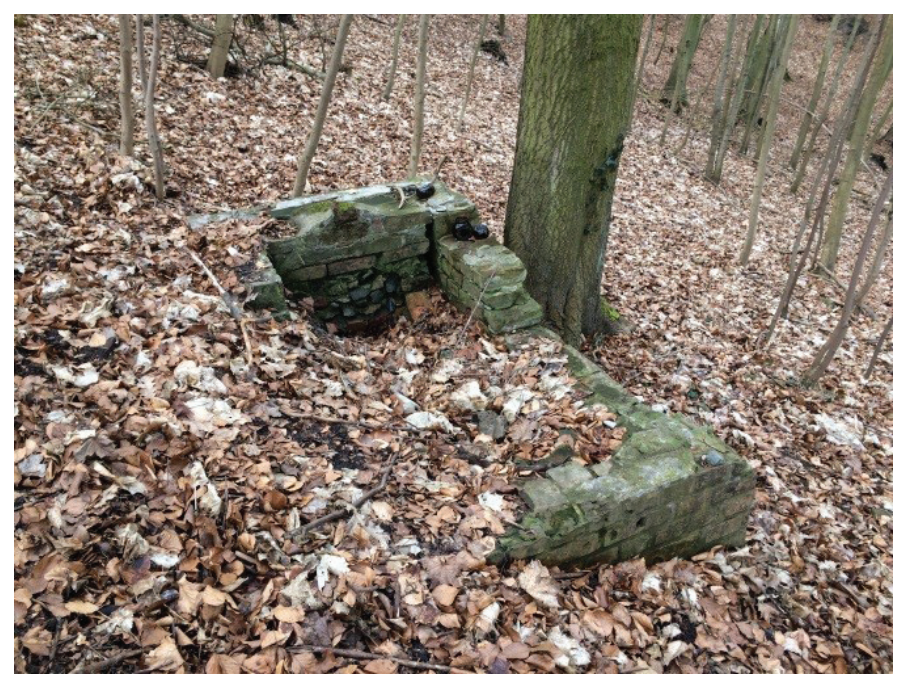

Figure 10: Neglected Jewish cemetery. Photo: K. Puzdrakiewicz. 


\subsection{The history of establishing and removing Gdańsk cemeteries}

Christianity had a decisive influence on burial practices in Europe. Since 1059, it has been obligatory to establish a graveyard near each and every church, and the dead could be buried only in the cemetery assigned to their parish. Subsequently, in the $12^{\text {th }}$ and $13^{\text {th }}$ centuries, along with the dissemination of monasteries, there was a possibility of burials in monastery cemeteries (Vovelle, 2008). The first known cemetery in Gdańsk existed already in the first half of the $11^{\text {th }}$ century. After it had been taken over by the Teutonic Order in 1308, Gdańsk underwent sweeping urban changes and they were visible in the city space until the World War II. Cemeteries were established in deliberately delimited areas around churches and underneath them. Only the elites were buried inside churches. During the medieval period, almost all churches performed the burial function. At that time, there were also separate hospital and asylum cemeteries where the patients were buried. Along with the city development, more cemeteries were needed. In the $17^{\text {th }}$ century, several cemeteries were established west to the city and their names reflected a social position of the dead buried there (e.g. Cemetery for Miserable Sinners, Cemetery for the Poor, Peasants' Hole). The cemeteries were expanding, and in the $18^{\text {th }}$ century they were given one name - Country of the Dead. Some burial sites were also established outside the city boundaries, for example Jewish cemeteries (since the times of the Teutonic Order Jews were not allowed to settle down within boundaries of Prussian cities) or epidemic cemeteries (e.g. after the plague of 1709) (Rozmarynowska, 2011; Szczepański \& Samól, 2011).

$2^{\text {nd }}$ September 1816 was a turning point in the history of Gdańsk cemeteries. On that day, the mayor J. H. Weickhmann issued an order according to which it was forbidden to bury people in the area surrounded by the city fortifications. As a result, new cemeteries were established in place of the old Country of the Dead, which was devastated during the first and second siege of Gdańsk. Since this order was issued, the burial role of churches was gradually diminishing (Kizik, 2011; Szczepański \& Samól, 2011). A dynamic increase in both the number and the area of cemeteries in Gdańsk has taken place since the $19^{\text {th }}$ centu- ry, when the practice of commemorating the dead, for example in form of a tombstone, became popular. The graves became even more personalised after introducing the 1804 decree according to which corpses had to be buried next to one another, not stacked (Ariès, 1989 as cited by Rosiek, 2011). Thus, in response to the need for more burial areas, several new parish cemeteries were established, mainly in the vicinity of Great Alley, north to the city centre. However, soon they were also full and in 1927 the communal Central Cemetery (Srebrzysko) was opened and it is still the second largest necropolis in the city (Kizik, 2011; Rozmarynowska, 2011; Szczepański \& Samól, 2011). The waterside location of the city and its spatial development prevented the creation of a ring of cemeteries around city centre, typical of cities such as Moscow, Vilnius and Paris. Generally, cemeteries were established in the west or north of the contemporary boundaries of the city, often in hilly and forested areas, which made them very attractive landscape. The aforementioned Central Cemetery, located in a forest valley, is considered a prestigious burial place with high landscape values.

Until the beginning of the World War II, there were 67 cemeteries in Gdańsk (Figure 11). After it had ended, the city became Polish, and all German citizens were displaced. It is worth mentioning that during the interwar period Germans constituted $90 \%$ of the city population. On $27^{\text {th }}$ September 1946 , a decision was issued, according to which 37 out of 48 existing cemeteries were closed down and another 7 were assigned a status of temporary burial sites. As this decision was not put into action, it was reissued in 1956 and 1961. Neglected and devastated cemeteries were removed, and some of them were transformed into public parks during the 1960s and the 1970s. In some cases, tree lines still reflect the old spatial structure of the former cemeteries. Not the process itself, but the way it was executed evokes controversy, as it had also been aimed at hiding the real history of those places. Tombstones were violently devastated and used as building material (Studium..., 2019; Szczepański \& Samól, 2011; Tölle, 2008). Nonetheless, Gdańsk was not the only place where such actions took place. Destroying German cemeteries and military monuments was a common practice in the so-called Recovered Territories 
(Pilarczyk, 2019; Pilarczyk, Nowak, 2019; Machura, 2011). Destroying German, Jewish or Mennonite cemeteries was aimed at erasing the memory of the unwanted predecessors (Gajewska, 2011). The negative attitude to the heritage of the Germans had a much wider context and resulted, among others, from the time of occupation or forced resettlement to the Regained Territories. The difficult socio-economic situation of Poles after World War II was not conducive to the willingness to care for cemeteries unrelated to their community. Social aversion to the legacy of its predecessors was also the result of communist propaganda at that time, which used the prevailing feelings to achieve its own goals.

As Figure 11 shows, World War II exerted the greater influence on the number of cemeteries in Gdańsk. Although they were mostly liquidated, two new military cemeteries were established during this period. The axis in Figure 11 presents also other important events (e.g. the 1709 plague and sieges of Gdańsk) which resulted in numerous casualties among the soldiers and civilians yet not all of them involved es- tablishing new burial sites in Gdańsk. Until the present times, 25 necropolises have remained.

\subsection{Functional and spatial changes of the former cemeteries}

According to Allam (2019), reusing former cemetery areas is a rational approach to modern urbanism. It is essential to separate religious issues from rational solutions aimed at improving the quality of life. In this part of the article, an analysis of the actual use of the post-cemetery areas and the spatial planning policy of the city regarding their future functions has been presented.

The analysis covers 75 post-cemeteries areas (ignoring two whose precise location is unknown). In many cases, the analysed areas perform multiple functions. In order to simplify the process of classification, a particular type of usage was assigned when it covered more than $15 \%$ of total area. The classification comprises 10 categories and 97 functions (land-use designations) (Figure 12).

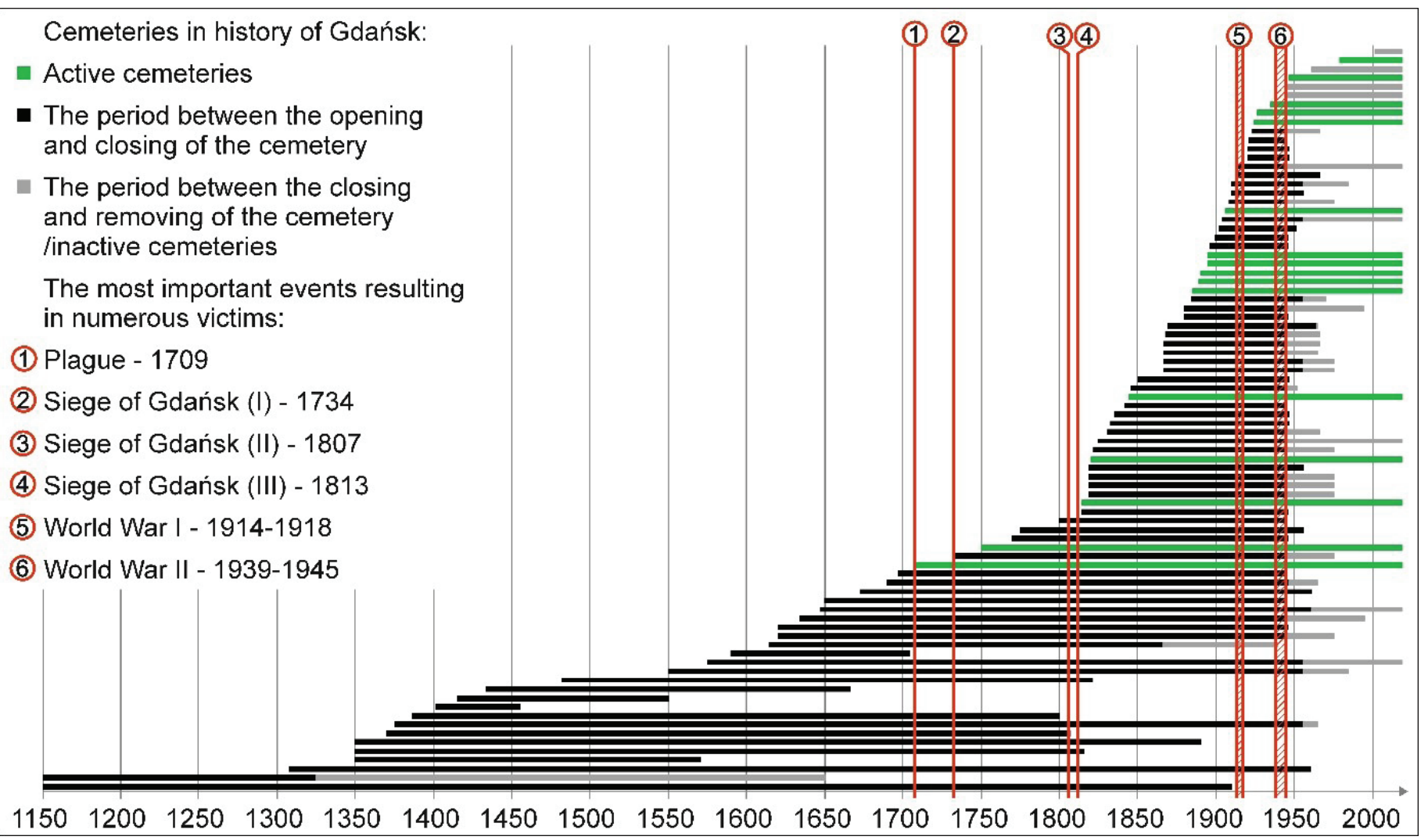

Figure 11. Existence periods of selected cemeteries in Gdańsk. Note: The figure presents only those cemeteries ( $\left.\sum=83\right)$ for which it was possible to determine dates of their opening and/or closing. For some cemeteries, only an approximate opening/closing period is known. In such cases, a date in the middle of the period was adopted. Source: Own elaboration based on dispersed sources. 


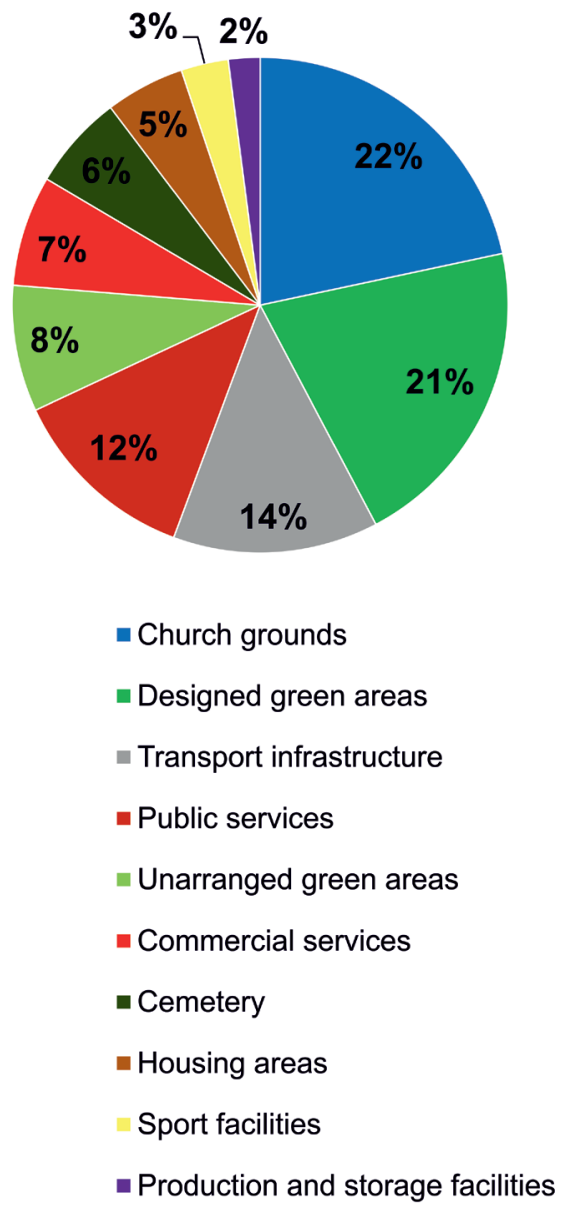

Figure 12. Real and current use of post-cemetery areas according to defined categories.

Several categories deserve special attention. The most frequent way of reusing post-churchyards is continuing their sacred function (with one exception of a destroyed and moved church). Therefore, it is more appropriate to say that the function was not changed, but lost (although in some cases old churchyards have been turned into designed green areas). There are some examples where old tombstones with inscriptions, underground catacombs or lapidariums have remained untouched.

In $21 \%$ of the analysed cases, the land-use designation has been completely changed. They are cemeteries turned into parks and other designed green areas. Usually, the old cemetery trees have not been removed, thanks to which the original spatial structures have been preserved. In Gdańsk, closed necropolises started to be transformed into urban parks in 1896-1897 when an old hospital cemetery was turned into Steffens' Park. At that time, it was the second largest park in the city. It was expand- ed in 1918, as another neighbouring inactive cemetery located along Great Alley was incorporated into it. Other cemeteries in this area were closed after World War II and turned into public parks in the 1960s and 1970s (Rozmarynowska, 2017; Rozmarynowska, 2011). Among the analysed parks and squares, there are five where playgrounds, open-air gyms or dog parks are present. $14 \%$ of the identified new land-use designations are connected with transport infrastructure, including roads, railway and tramlines, car parks, one bus station and a tram depot. Although this category was quite frequently identified, transport infrastructure does not usually cover a large percentage of post-cemetery areas. In most cases, transport infrastructure was constructed after the cemeteries had been turned into parks. $26 \%$ of the new functions regard mixed usage, including housing, service or production areas. In $6 \%$ of the cases, closed and formally non-existing burial sites (or their parts) have been turned into new cemeteries (e.g. in Oliwa four old cemeteries have been transformed into one communal necropolis). The three main intensity levels of land use change after former cemeteries are shown in Figure 13.

According to the analysis, the most frequent ways of transforming post-cemetery areas were parks or areas of various functions, including housing, service and production. However, there are some exceptional cases of introducing radical changes, still considered highly controversial. They are as follows: a bus station in Śródmieście [Downtown] built in 1971 in place of three cemeteries, closed after World War II and removed in 1970; a discount shop in Nowy Port built in place where in 1842-1945 a small parish cemetery used to be; an storage area for industrial materials of the Chemical Plant in Stogi (1673-1961), a detention ward in Śródmieście [Downtown] (mid$19^{\text {th }}$ century -1947 ) and several examples of housing estates (including those built in place of cemeteries removed in 1945-1984).

The study of conditions and development directions is a document determining a municipality's spatial policy, which is translated into local laws in the form of a municipal master plan. Therefore, it is a good material for an analysis of the future use of the analysed areas. The analysis, covering 75 sites, allowed determining 97 functions (land-use designations) 


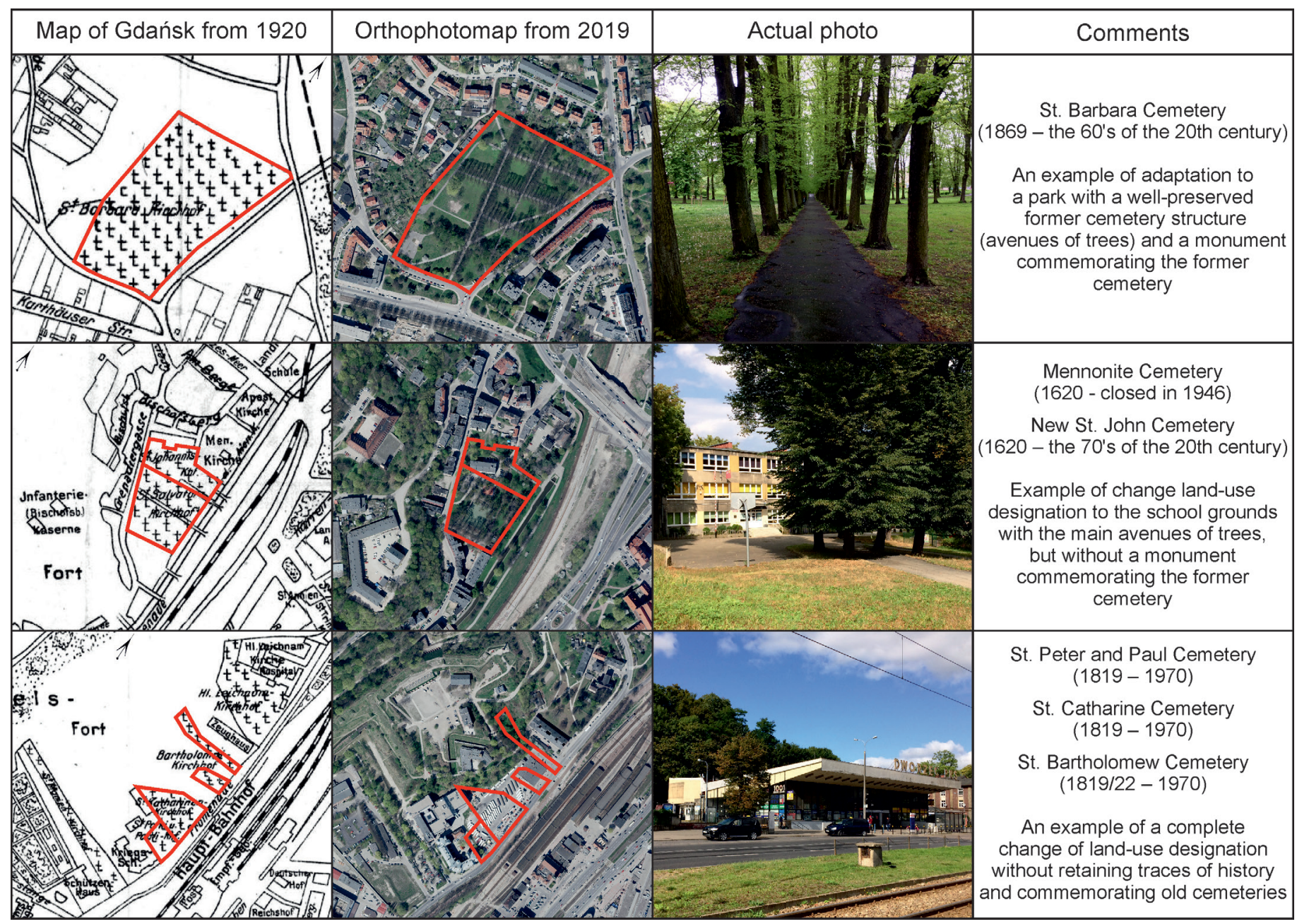

Figure 13. Examples of change of land-use designations after former cemeteries. Source: Archiwalne Mapy Pomorza Gdańskiego (2019), Geoportal (2020). Photo: K. Puzdrakiewicz.

(Figure 14). Moreover, it was possible to estimate the percentage of areas covered by the determined land-use designations (Figure 15).

The analysis showed that there are no essential changes planned in the context of the current use of post-cemetery areas. It is especially important that the existing public green areas are not planned to be disrupted. Most of the post-cemetery areas (57\%) will be part of the green areas of the city. Functions of the already built-up areas will not be changed.

\subsection{Current spatial policy of the city on cemetery areas}

Although 25 cemeteries have been identified, the official planning documents issued by the city authorities mention only 14 of them (mainly communal and parish cemeteries yet not all of them), excluding symbolical, military and Jewish ones (although some of them are marked on the map being attachments to those documents). This chapter discusses the current policy of the city on the existing and future cemeteries.

According to the current spatial development plan, 10 existing and active cemeteries will be enlarged, and 3 new necropolises will be established (Table 1, Figure 16) in the future. When completing those provisions, burial space in Gdańsk will be enlarged by 21.9 ha. The analysis of the actual demand has indicated that in the period of 2017-2045 the area of burial space in the city should be enlarged by 23.4 ha. Including 2.5 ha of free space within the already existing cemetery in Łostowice, it seems that the actual demand will be covered with a reserve of 1 ha. It is assumed that the cremation rate will increase to $55 \%$ in the future while in 2016 it was $43 \%$ and in 2012 - 31\% (Tisler \& Turzyński, 2019; Tisler \& 


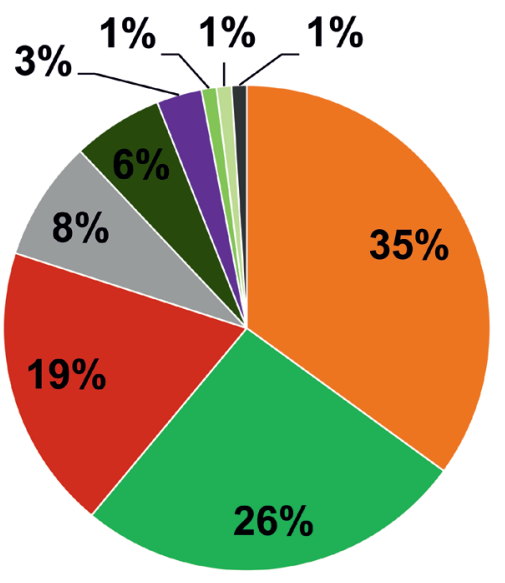

- Services and housing

- Green areas (parks and squares)

- Non-primary services

- Transport infrastructure (road and rail areas)

- Cemetery

- Production and storage facilities, harbour area

$=$ Forests and forest parks

Allotment gardens

- Urban infrastructure (tram depot)

Figure 14. Planned land-use designations of the post-cemetery areas.

Turzyński, 2012). In 2018 a decision was made not to maintain a land reserve ( $50.0 \mathrm{ha}$ ) for a new cemetery in the western part of the city, where allotment gardens are located at present. This reserve was supposed to have covered the demand for burial space in case of any negative changes in the cremation rate, yet there is no indication that it would happen. The planned spatial distribution of burial sites in Gdańsk is relatively balanced and it provides all citizens accessibility to graves of their relatives and loved ones (Studium..., 2019; Studium..., 2007). This is a clear departure from the model of building several large cemeteries remote from the housing areas to fragmenting and making new areas available for burial functions near housing developments.

In conclusion, all the changes regarding the already existing and future burial sites in Gdańsk are planned to take place mainly within unarranged green areas and forests (areas currently not covered by any investment). The only changes regarding the already built-up areas concern a park and housing estate. In four cases, there is a plan to restore the burial

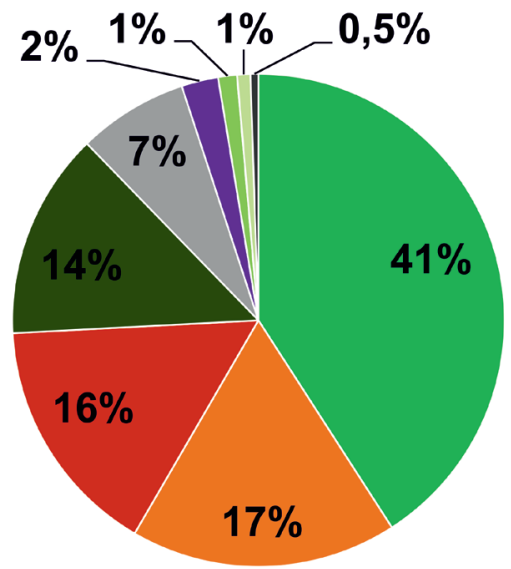

- Green areas (parks and squares)

- Services and housing

- Non-primary services

- Cemetery

- Transport infrastructure (road and rail areas)

- Production and storage facilities, harbour area

Forests and forest parks

Allotment gardens

- Urban infrastructure (tram depot)

Figure 15. Planned land-use designations of the post-cemetery areas by the percentage of area covered.

function in places where cemeteries used to be in the past. One of them is a former cemetery where some gravestones still remain. They receive proper care and are in good condition. Another area is a former cemetery, which has been transformed into a park, and the two remaining ones are neglected old cemeteries. Restoring the burial function, called by Wacław (2011) a process of cemetery revitalisation, is usually perceived positively. However, it is not always possible to do so due to sweeping spatial changes, which have taken place in a cemetery area itself or its vicinity. There are no plans to remove the existing cemeteries, regardless of their activity status. The approach of the current self-government in creating the spatial policy is clearly different from that in post-war times. This reflects the attitude of the modern community to the already familiarised space as well as an increasing interest and need to commemorate objects crucial for the place identity, which was especially true in the first decade of the $21^{\text {st }}$ century in post-German cities of western and northern Poland (Pilarczyk, 2019). 
Table 1. Development plans regarding cemeteries in Gdańsk. Source: Own elaboration based on dispersed sources.

\begin{tabular}{|c|c|c|c|c|c|c|}
\hline SN & Cemetery name & District & $\begin{array}{l}\text { Cemetery } \\
\text { type }\end{array}$ & $\begin{array}{c}\text { Planned } \\
\text { investment }\end{array}$ & $\begin{array}{c}\text { Current/ } \\
\text { planned area } \\
\text { [hectare] }\end{array}$ & Current land-use form \\
\hline 1 & Św. Walentego & Matarnia & communal & development & $0.88 / 1.41$ & $\begin{array}{l}\text { unarranged green area, } \\
\text { church grounds }\end{array}$ \\
\hline 2 & Św. Jana Chrzciciela & $\begin{array}{c}\text { Kokoszki Mieszka- } \\
\text { niowe }\end{array}$ & parish & development & $0.19 / 0.29$ & unarranged green area \\
\hline 3 & Centralny Srebrzysko & Wrzeszcz Górny & communal & development & 28.03 / 34.93 & unarranged green area \\
\hline 4 & Łostowicki & Zakoniczyn-Łostowice & communal & development & $50.15 / 51.95$ & unarranged green area \\
\hline 5 & Św. Jadwigi & Nowy Port & communal & development & $1.59 / 2.54$ & $\begin{array}{l}\text { designed green area (part } \\
\text { of a cemetery closed in } \\
1947 \text { and then removed in } \\
\text { the 1970s) }\end{array}$ \\
\hline 6 & Garnizonowy & Siedlce & communal & development & \multirow[t]{2}{*}{$4.58 / 6.75$} & \multirow{2}{*}{$\begin{array}{l}\text { housing area and partially } \\
\text { unarranged green areas } \\
\text { (cemetery closed in } 1946 \\
\text { and then removed in the } \\
\text { 1970s) }\end{array}$} \\
\hline 7 & Bożego Ciała & Siedlce & communal & development & & \\
\hline 8 & Nowy Salvator & Chełm & communal & development & $0.65 / 1.49$ & unarranged green area \\
\hline 9 & Św. Ignacego & Chełm & communal & development & $2.03 / 3.23$ & unarranged green area \\
\hline 10 & Najśw. Imienia Maryi & Stogi Mieszkaniowe & parish & development & $1.55 / 2.96$ & forest \\
\hline 11 & - & Brętowo & communal & construction & $-/ 1.90$ & cemetery closed in $1956 \mathrm{r}$. \\
\hline 12 & - & Stogi Mieszkaniowe & communal & construction & $-/ 2.70$ & $\begin{array}{l}\text { unarranged green area and } \\
\text { woods (including } 0.90 \text { ha of } \\
\text { a former cemetery, closed } \\
\text { in 1994) }\end{array}$ \\
\hline 13 & - & Wyspa Sobieszewska & communal & construction & $-/ 1.40$ & forest \\
\hline
\end{tabular}

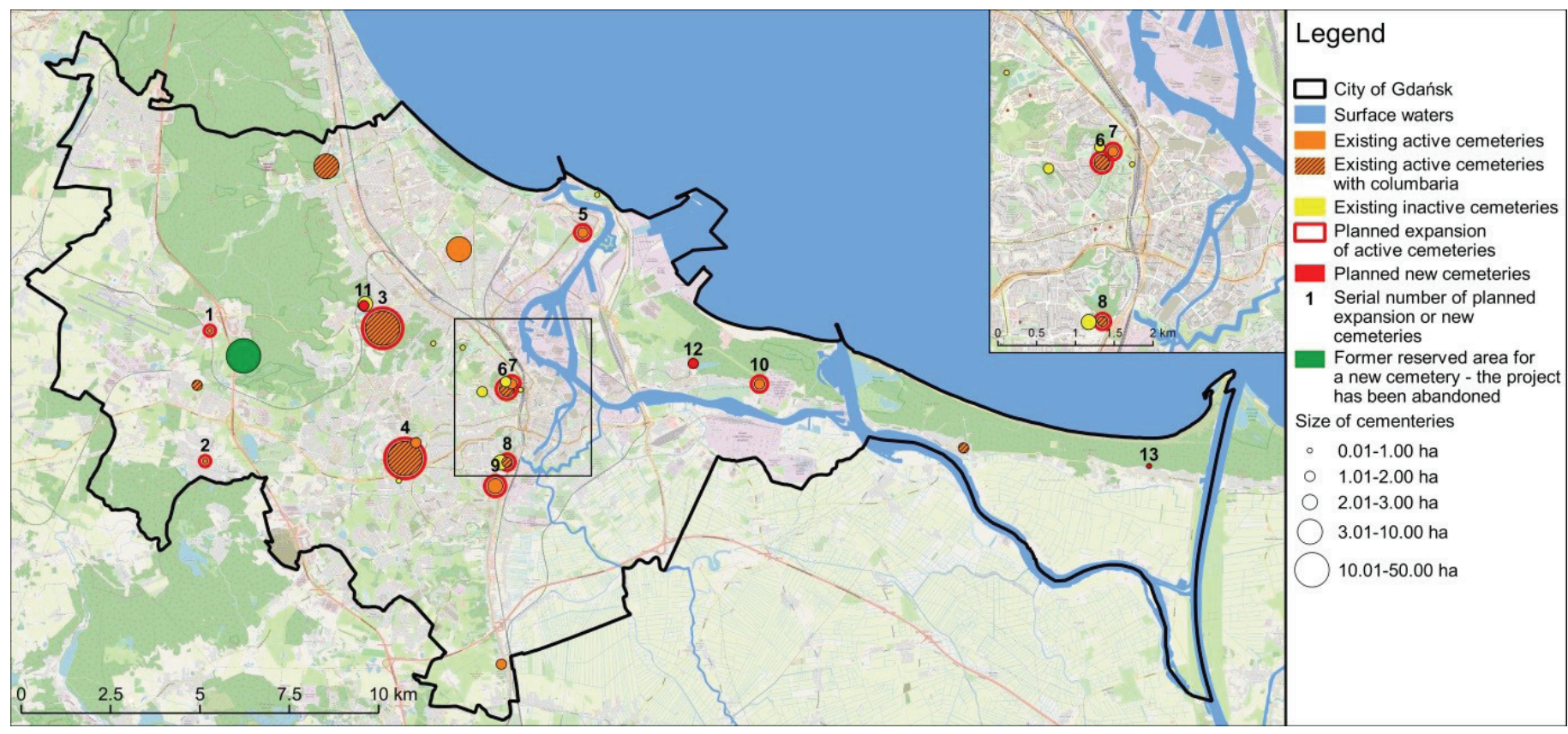

Figure 16. Current state and development plans for the burial space in Gdańsk. Source: Own elaboration based on dispersed sources. 
Due to significant investment limitations of cemeteries and the assigned function limiting transformations for other purposes, they are not a priority for the city authorities when adopting municipal master plans in their area. Currently, municipal master plans are prepared only for areas where establishing or enlarging the existing cemeteries is planned (Studium..., 2019; Studium..., 2007). However, most of the existing active cemeteries were covered with the municipal master plans (13 out of 16 cemeteries). They are part of the city-wide system of biologically active areas where tall greenery is protected. Moreover, these are usually zones of archaeological protection and protection of historic objects, such as old tombstones, chapels, fences or historical spatial structures. It is forbidden to place advertisements on their area. Taking into account 9 inactive cemeteries, 6 of them have a municipal master plan, of which two are considered cemeteries, three as public greenery and one as a service area with greenery.

\subsection{Social perception of removal of cemeteries and their functional changes}

Public opinion polls are significant tools supporting the development of sustainable urban development. The same space may be perceived differently by experts, being key actors in the process of shaping the urban landscape, and by citizens (Hofmann et al., 2012). Cemetery areas, being commonly perceived as sacred, are very interesting research objects. This chapter has been devoted to investigating the inhabitants' perception of removing cemeteries, changing their function and commemorating. Such a research problem has not been analysed in the context of social studies yet, although some cases of social protests and controversies regarding the process of changing the primary function of cemetery areas have been mentioned in the literature (Klaufus, 2016). According to the law, a change in the function of a cemetery area must be preceded by setting out the municipal master plan. The planning procedure public participation is ensured in the form of consultations and a possibility to file petitions and comments to projects. Unfortunately, residents rarely participate in this type of activities, which limits the planners' ability to identify social needs accurately. Therefore, a need to identify social feelings towards the problem is identified. Table 2 presents the respondents' profile.

Table 2. Profile of the respondents taking part in the survey.

\begin{tabular}{|l|c|c|}
\hline Profile of the respondents & Number & $\%$ \\
\hline Gender & 255 & 59.4 \\
\hline Female & 174 & 40.6 \\
\hline Male & 159 & 37.1 \\
\hline Age & 86 & 20.0 \\
\hline $18-30$ & 70 & 16.3 \\
\hline $31-45$ & 114 & 26.6 \\
\hline $46-60$ & & \\
\hline older than 61 & 36 & 8.4 \\
\hline Education & 162 & 37.8 \\
\hline primary & 231 & 53.8 \\
\hline secondary &
\end{tabular}

The first question of the survey was "Should old/inactive cemeteries be removed (i.e. those where the last burial took place 40 or more years ago)?" According to Polish legal regulations, a cemetery may be removed at least 40 years after the last burial. Monumental cemeteries are taken into consideration here as they are under special legal protection and, even more importantly, they are of considerable value to society as a whole. However, most of the respondents $(58.7 \%)$ state that even is such a case cemeteries should not be removed. $25.2 \%$ of the respondents admitted that old cemeteries should be removed, and $16.1 \%$ of them chose the answer "don't know". However, the relation between the provided answers and the respondents' age is very thought provoking. The older the respondents, the more positive answers $(18.2 \%, 24.4 \%, 27.1 \%$ and $34.2 \%$ respectively). The respondents aged 18-30 and $31-45$ usually gave negative answers (63.0\%). A similar correlation can be observed when analysing the level of education. The higher the level, the more negative answers. There are no significant differences in regard to the respondents' gender $(7.0 \%$ more women were against removing old cemeteries).

The second question referred to exhumation procedures carried out when removing a cemetery. Polish law requires that all human remains should be 
relocated to other burial sites. However, during the 20th century there were numerous cases when this requirement was not observed and only the ground structure of cemeteries was destroyed without performing full exhumation (in some cases only partial exhumation was performed). Examples include old cemeteries along Great Alley transformed into parks without performing the exhumation procedures (Krüger, 2011). As a result, some human remains can still be found during earthworks, and each such case receives wide media and public attention. The question is not aimed at undermining the existing legal regulations but at determining social attitudes to the exhumation process in the context of removing old cemeteries. The question "Should full exhumation be performed when removing an old cemetery?" was positively answered by $62.2 \%$ of the respondents, negatively by $18.4 \%$, and $19.4 \%$ chose the "I don't know" option. Similar relationships between age, education and gender are observed as in the case of Question 1. The older the respondents, the more positive answers. The more educated the respondents, the more negative ones.
Social perception of removing cemeteries and changing their primary function may not only depend on cultural and religious factors, but also on some exceptional circumstances under which the process is carried out. In Question 3, the respondents were asked to determine what functions (landuse designations) may be assigned to post-cemetery areas (Figure 17).

Description of categories: I - designed green areas (parks, squares), II - designed green areas with playgrounds, open-air gyms or dog parks, III - unarranged green areas (wastelands, woods, allotment gardens), IV - sports and recreation facilities (pitches, courts, sports centres, swimming pools), $\mathrm{V}$ - housing, VI-commercial services (shops, cinemas, hotels, restaurants), VII - public services (schools, hospitals, public administration), VIII - production and storage facilities, IX - transport infrastructure (roads, pavements, car parks, depots, railway lines).

Additionally, examples of all the listed functions may be found in Gdańsk. Therefore, it may be stated that answers to this question reflect the level of social approval of the already implemented functional

What functions should or should not be assigned to post-cemeteries areas?

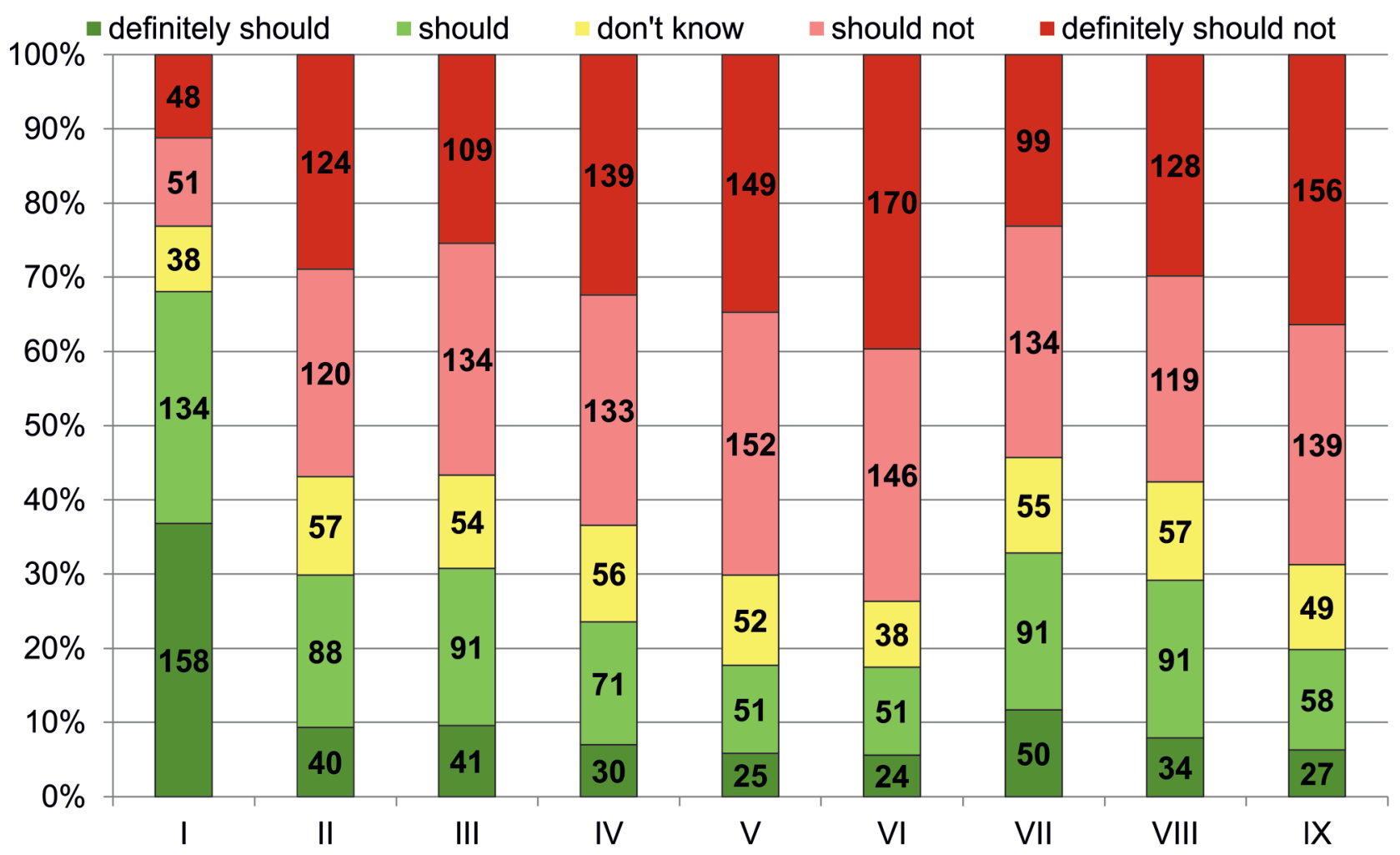

Figure 17. New functions of post-cemetery areas and their social acceptance. 
changes. Transforming old cemeteries into parks, yet with no additional infrastructure like playgrounds, open-air gyms or dog parks, gained the highest level of social acceptance (68.1\%). However, $29.8 \%$ of the respondents do not mind the additional infrastructure mentioned above. The most controversial are the dog parks, which have been constructed in three post-cemetery parks in Gdańsk (the conclusion is mainly drawn from numerous comments added by the respondents while filling in the survey). There is also a belief that each burial site, no matter whether active, closed or removed, is a sacred place and it should not be turned into spaces for leisure or playing. The survey has shown that it is socially acceptable to transform post-cemetery areas into designed green spaces, but with no additional facilities or solid infrastructure (54.3-73.7\% of negative answers). However, transforming post-cemetery areas into unarranged green spaces gained a relatively low level of acceptance (30.8\% of positive answers), which is, in fact, quite surprising.

Public and commercial services are differently perceived in the context of the post-cemetery areas. More respondents (32.9\%) were in favour of transforming post-cemetery areas into places where public services are provided, including administration facilities, schools or health centres. Only $17.5 \%$ of them do not mind providing commercial services in such places, e.g. hotels, restaurants and shops. On average, the option "I don't know" was chosen by $11.8 \%$ of the respondents, and there was no category being particularly difficult to assess. The respondents' gender does not have a significant impact on the results (differences between 0.0 and $7.7 \%$ ). When analysing the results in the context of the respondents' age, there is a visible trend for most of the assessed categories/functions. Namely, the older the respondents, the more negative answers (with an exception of category IX). Generally, the level of education is not a differentiating factor in the case of Question 3. Yet, for categories I and VII, there is a significant relationship between the level of education and the answers given. The higher the education level, the more positive answers.

The last question concerned ways of commemorating places where cemeteries used to be. According to the legal system, the way in which a removed religious cemetery will be commemorated is determined by church or religious group authorities before a decision to remove is issued. During the period of 2006-2009, some of Gdańsk cemeteries turned into parks or squares were commemorated. There are symbolic gravestones providing information on the name of the former cemetery, its religious affiliation and the period of its existence (in Polish and German). On the gravestones there are also maps showing the area which used to be covered by given cemeteries (Figure 18). In total, 15 such gravestones were funded by the City Hall, but still not all former cemeteries transformed into parks or other green spaces have been commemorated ( 5 have not been commemorated); not to mention the post-cemetery areas assigned different functions. Currently, the city is not planning to commemorate other former cemeteries within the next few years. The only application to commemorate a cemetery transformed into school grounds submitted to the City Hall has not been evaluated yet.

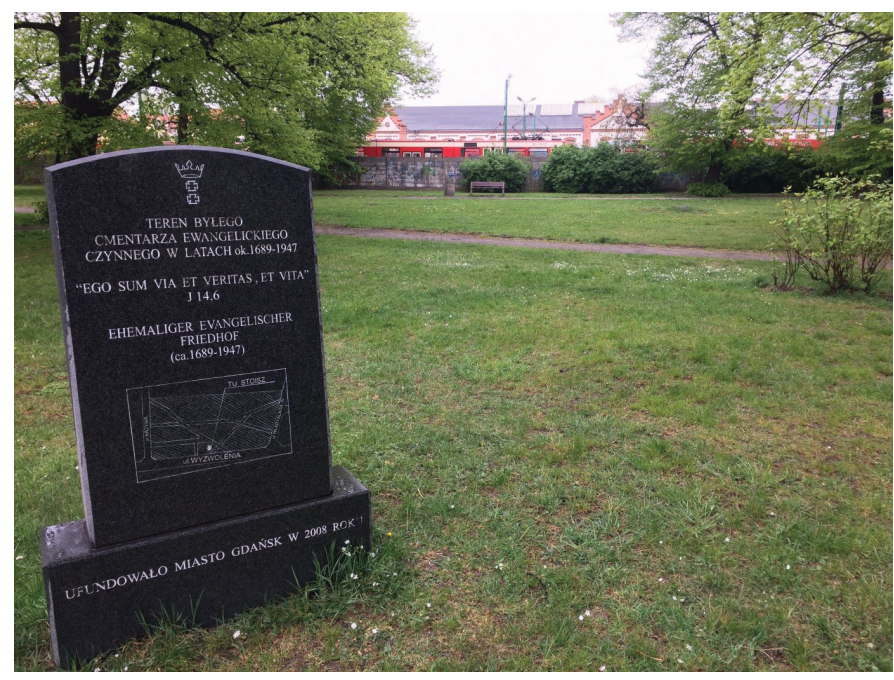

Figure 18. Gravestone commemorating the former cemetery in Nowy Port (turned into a public park and a tram depot). Photo: K. Puzdrakiewicz.

The question if the places where cemeteries used to be should or should not be commemorated (in a form of a monument or an information board) was positively answered by the majority $(88.1 \%)$ of the respondents. Only $3.7 \%$ answered negatively, and $8.2 \%$ of them had no opinion. Therefore, it is obvious that the idea of commemorating particular places, not only creating the Cemetery of Non-existing Cemeteries, is socially approved. It is of great importance 
for the city semiotics as some post-cemetery areas are literally invisible to the contemporary citizens, and this disrupts the process of creating local identity based on the memory of the dead and respect to the city's history. In the case of the last question, no significant relationships between the answers given and the respondents' profile data have been identified.

\section{Conclusions}

Changes taking place in the functional and spatial structure of cities are dynamic and affect important areas, such as cemeteries. In the case of Gdańsk cemeteries, the most significant changes took place after World War II. The city incorporated into Poland underwent a social and political revolution. The immigrating population was not related to the place it took over, did not understand the adopted forms of development, and did not have a developed local identity. Centralised communist authorities carried out activities aimed at strengthening resentment towards Germans and their heritage in the so-called Recovered Territories, which was in fact facilitated by the generally difficult situation of Poles in the post-war times and a negative attitude towards the former occupying forces. As regards the majority of Gdańsk cemeteries, three decisions were taken in the 1960s and 1970s to close down and remove them. Most of these cemeteries were neglected (the descendants of the buried persons were displaced) and devastated by the inhabitants (Figure 19).

44 years since the end of the war, Poland became a democratic country in which local authorities were independent in pursuing their policy. Due to the passage of time, the current Gdańsk society is mostly made up of people born in this city, which helped develop local identity and familiarised the city's space, including the predecessors' legacy. The increase in public awareness and in interest in the city's history has resulted in a need to commemorate former cemeteries as places of inalienable value of the sacrum. The first such activity was to create the symbolic Cemetery of Non-Existing Cemeteries, then monuments commemorating some of the removed cemeteries in public green areas and in the Nostalgic Park. The city authorities do not plan new removals of cemeteries or interference in the current functioning of post-cemetery areas. However, a new process of restoring burial functions in some non-existent cemeteries (revitalization of cemeteries) was initiated by adopting such a function in planning documents. These arrangements have not yet been implemented. There is a visible change in the approach to the predecessors' legacy, from re-

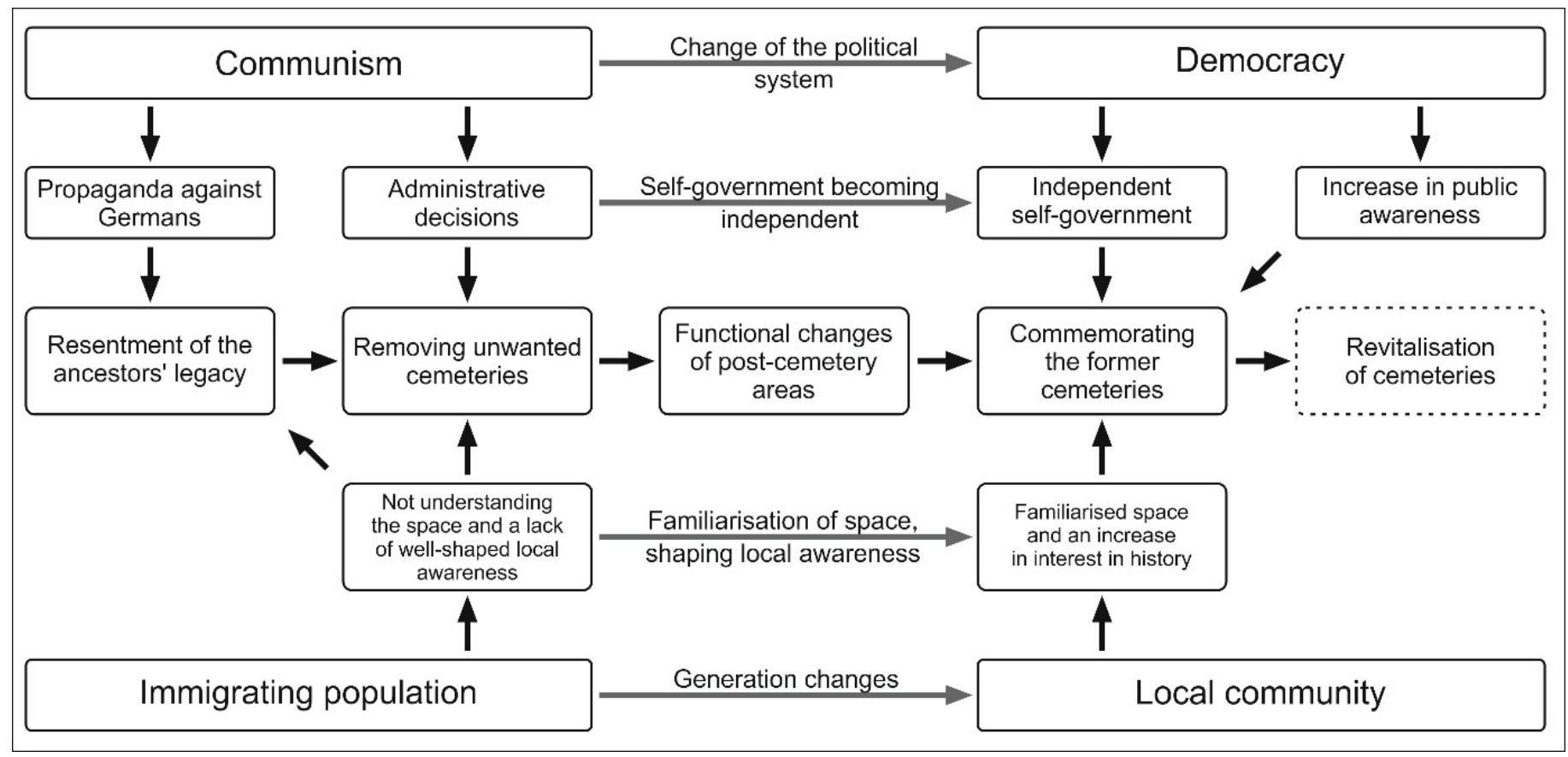

Figure 19. Change in the approach to Gdańsk cemeteries as a legacy of the previous community. 
sentment in post-war times, when Polishness was being shaped in the Recovered Territories, to commemorating and restoring the functions of cemeteries regardless of their religious and national affiliation at that time.

The above is confirmed by conclusions from the conducted survey. Among the current population of Gdańsk there is noticeable attachment to the existing cemeteries and a negative perception of most of the implemented conversions of the removed ones. The only acceptable form of use of the post-cemetery area is public greenery arranged without controversial facilities, such as playgrounds, outdoor gyms and dog parks. Thus created parks and squares should contain elements commemorating the past of these places (e.g. in the form of monuments or information boards) so that the memory of their unique history could continue. This is also important for the conscious perception of space by its users. A removal of a cemetery should be accompanied by full exhumation of corpses, which was not observed in all functional transformations of the former cemeteries in Gdańsk.

\section{References}

Act of 31 January 1959 on Cemeteries and Burial of the Deceased (Journal of Laws Dz.U. from 2019, No. 1473, item 1473).

Al-Akla, N. M., Karaana, E. N., Al-Zeinb, M. S., \& Assaadc, S. 2018. The landscape of urban cemeteries in Beirut: Perceptions and preferences. Urban Forestry \& Urban Greening, 33, 66-74, DOI: 10.1016/j.ufug.2018.04.011.

Allam, Z. 2019. The city of the living or the dead: On the ethics and morality of land use for graveyards in a rapidly urbanised world. Land Use Policy, 87, 104037, DOI: 10.1016/j.landusepol.2019.104037.
Archiwalne Mapy Pomorza Gdańskiego, https:// mapy.eksploracja.pl/news.php [Accessed 15 April 2019].

Ashton, J. 2019. Necropolis in crisis: housing the living is one thing, there is also a problem in housing the dead. Journal of the Royal Society of Medicine, 112(7), 313-315, DOI: $10.1177 / 0141076819860091$.

Basmajian, C., \& Coutts, C. 2010. Planning for the Disposal of the Dead. Journal of the American Planning Association, 76(3), 305-317, DOI: 10.1080/01944361003791913.

Borzyszkowska-Szewczyk, M. 2011. Unforgetting in a Borderland. Jewish Cemeteries in Kashubia as a Space of (un)Remembrance? [in:] Borzyszkowski, J. (eds.) Nekropolie Pomorza, Gdańsk, pp. 580596.

Central Statistical Office, 2018. Życie religijne w Polsce. Wyniki badania spójności społecznej 2018 (Religious life in Poland. The results of 2018 coherence analysis).

Central Statistical Office, https://stat.gov. pl/metainformacje/slownik-pojec/ pojecia-stosowane-w-statystycepublicznej/2681,pojecie.html [Accessed 18 May 2019].

Davies, P. J., \& Bennett, G. 2016. Planning, provision and perpetuity of deathscapes - Past and future trends and the impact for city planners. Land Use Policy, 55, 98-107, DOI: 10.1016/j. landusepol.2016.03.029.

Długozima, A. 2011. Cmentarze jako ogrody żywych i umarłych (Cemeteries as gardens of the living and the dead), Warszawa. 
Długozima, A., \& Rej, M. 2014. Contemporary trends in European cemeteries design. Space \& Form, 21, 403-416.

Evensen, K., Nordh, H., \& Skaar, M. 2017. Everyday use of urban cemeteries: A Norwegian case study. Landscape and Urban Planning, 159, 76-84, DOI: 10.1016/j.landurbplan.2016.09.019.

Folíková Palánová, \& K., Juračka, O. 2018. Sustainability of existing areas of historic cemeteries in the city organism: A Czech case study. IOP Conference Series Earth and Environmental Science 143(1):012052, DOI: 10.1088/1755-1315/143/1/012052.

Francis, D. 2003. Cemeteries as cultural landscapes. Mortality, 8(2), 222-227, DOI: $10.1080 / 1357627031000087442$.

Gajewska, M. 2011. The Cemetery Beyond Cemetery [in:] Borzyszkowski, J. (eds.) Nekropolie Pomorza, Gdańsk, pp. 76-85.

Gedanopedia, https://www.gedanopedia. $\mathrm{pl} /$ ?title=CMENTARZE [Accessed 20 June 2019].

Geoportal, https://geoportal.gov.pl/dane/ ortofotomapa?p_p_id=56_INSTANCE_ o 9 uyz7g1Zkan\&p_p_lifecycle $=0 \& p_{-} p_{-}$ state $=$ normal\&p_p_state_rcv $=1$ [Accessed 19 September 2020].

Grabalov, P. 2018. Public life among the dead: Jogging in Malmö cemeteries. Urban Forestry \& Urban Greening, 33, 75-79, DOI: 10.1016/j. ufug.2018.01.027.

Hofmann, M., Westermann, J. R., Kowarik, I., \& van der Meer, E. 2012. Perceptions of parks and urban derelict land by landscape planners and residents. Urban Forestry \& Urban Greening, 11(3), 303312, DOI: 10.1016/j.ufug.2012.04.001.
Holly, G. 2007. Stan zachowania zabytkowych cmentarzy chrześcijańskich na terenie Bieszczadzkiego Parku Narodowego (The state of preservation of historic Christian cemeteries in the area of the Bieszczady National Park). Roczniki Bieszczadzkie, 15, 305-342.

Janicki, D. 2014. Cmentarze w polskim prawie administracyjnym (Cemeteries in Polish administrative law). Security, Economy \& Law, 4, 4-21.

Jażdżewski, L. 2012. Nekropolia Męczenników II wojny światowej. Historia cmentarza na Zaspie (Martyrs of World War II Necropolis. The history of Zaspa cemetery), Wydawnictwo ROST, Gdańsk.

Kizik, E. 2011. Burial Prohibition in Gdańsk Churches and Churchyard Cemeteries in 1816. The Beginning of Change in the Funeral Culture in the 19th Century [in:] Borzyszkowski, J. (eds.) Nekropolie Pomorza, Gdańsk, pp. 245-263.

Klaufus, C. 2014. Deathscapes in Latin America's Metropolises: Urban Land Use, Funerary Transformations, and Daily Inconveniences. European Review of Latin American and Caribbean Studies, 96, 99-111, DOI: 10.18352/erlacs.9469.

Klaufus, C. 2016. Deathscape politics in Colombian metropolises: Conservation, grave recycling and the position of the bereaved.UrbanStudies, 53(12), 2453-2468, DOI: 10.1177/0042098015593012.

Knercer, W. 1995. Cmentarze wojenne z okresu I wojny światowej w województwie olsztyńskim (War cemeteries from the period of World War I in the Olsztyn Voivodeship). OOZK, Warszawa.

Kolbuszewski, J. 1996. Cmentarze (Cemeteries), Wydawnictwo Dolnośląskie, Wrocław. 
Kolnberger, T. 2018. Cemeteries and urban form: a historico-geographical approach. Journal of Urban Morphology, 22(2), 119-139.

Kong, L. 2012. No Place, New Places: Death and its Rituals in Urban Asia. Urban Studies, 49(2), 415433, DOI: 10.1177/0042098011402231.

Kość-Ryżko, K. 2011. Customary Manners of Giving Deceased into Other World in the Polish Traditional Culture (19th-20th Century) [in:] Borzyszkowski, J. (eds.) Nekropolie Pomorza, Gdańsk, pp. 106-127.

Krüger, A. 2011. Some Information about History of St. Catharine Cemetery near the Great Alley in Gdańsk in 19th Century [in:] Borzyszkowski, J. (eds.) Nekropolie Pomorza, Gdańsk, pp. 299-308.

Krüger, A. 2016. Cmentarz garnizonowy w Gdańsku. Miejsce pamięci ofiar komunizmu (Garrison cemetery in Gdańsk. Victims of Communism Memorial Site), Instytut Pamięci Narodowej, Gdańsk.

Krupar, S. R. 2017. Green death: sustainability and the administration of the dead. Cultural Geographies, 25(2), 267-284, DOI: $10.1177 / 1474474017732977$.

Kubiak, A. E. 2018. Civilized and wild heterotopia the case of the Polish cemeteries. Anthropological Researches and Studies, 8, 276-284, DOI: 10.26758/8.1.27.

Labenz, J. 1999. Gdańskie cmentarze. Studium historyczno-konserwatorskie, czyli historia rozwoju założeń cmentarnych na obszarze Gdańska z wyszczególnieniem chronologii, lokalizacji oraz przynależności wyznaniowej (Gdańsk Cemeteries. History and Conservation. The history of burial sites development in Gdańsk including chronology, location and religious affiliation), manuscript.
Lai, K.Y., Scott, I., \& Sun, Z. 2019. Everyday Use of the City Cemetery: A Study of Environmental Qualities and Perceived Restorativeness in a Scottish Context. Urban Sci., 3, 72, DOI: 10.3390/ urbansci3030072.

Lewicka, B. 2017. Nekropolie. Socjologiczne studium cmentarzy Katowic (Necropolises. Sociological study of cemeteries in Katowice), Wydawnictwo Uniwersytetu Śląskiego, Katowice.

Libura, H. 1990. Percepcja przestrzeni miejskiej (Perception of urban space), Warszawa.

Local Data Bank, Central Statistical Office, https:// bdl.stat.gov.pl/BDL/dane/teryt/tablica [Accessed 08 June 2020].

Machura, W. 2011. Soldier Monuments in Middle Pomerania from the Napoleonic Wars to World War II [in:] Borzyszkowski, J. (eds.) Nekropolie Pomorza, Gdańsk, pp. 553-579.

Majewska, A. 2020. Continuity and Decline. Temporal Expression of Denominational Cemeteries in Contemporary Times. Acta Universitatis Lodziensis Folia Archaeologica, 34(34), 71-96, DOI: 10.18778/0208-6034.34.05.

Majewska, A., Worobiec, K., \& Bugowska E. 2019. Locality in the era of globalization. Carriers of the memory of historical landscapes - studies on the Evangelical cemeteries of the Masuria region (Poland). Studies in Political and Historical Geography, 8, 227-246, DOI: 10.18778/23000562.08.12.

Majewska, A. 2017. Jewish sepulchral heritage in Silesian voivodeship divided by the borders. Similarities and differences. Region and Regionalism, 13(2), 147-167. 
McClymont, K. 2018. 'They Have Different Ways of DoingThings': Cemeteries, Diversityand Local Place Attachment. Journal of Intercultural Studies, 39:3, 267-285, DOI: 10.1080/07256868.2018.1459519.

Neckel, A., Costa, C., Mario, D. N., Sabadin, C. E. S., \& Bodah, E. T. 2017. Environmental damage and public health threat caused by cemeteries: a proposal of ideal cemeteries for the growing urban sprawl. urbe. Revista Brasileira de Gestão Urbana, 9(2), 216-230, DOI: 10.1590/21753369.009.002.ao05.

Nordh, H., \& Evensen, K. H. 2018. Qualities and functions ascribed to urban cemeteries across the capital cities of Scandinavia. Urban Forestry \& Urban Greening, 33, 80-91, DOI: 10.1016/j. ufug.2018.01.026.

Nordh, H., Evensen, K. H., \& Skår, M. 2017. A peaceful place in the city-A qualitative study of restorative components of the cemetery. Landscape and Urban Planning, 167, 108-117, DOI: 10.1016/j. landurbplan.2017.06.004.

Pasierb, J. St. 1995. Ochrona zabytków sztuki kościelnej (Protection of monuments of church art), Biblioteka Towarzystwa Opieki nad Zabytkami, Warszawa.

Pilarczyk, A. 2019. Methods of commemorating liquidated cemeteries and former cemetery areas as an expression of remembrance, relief, and respect for a sacred place. Technical Transactions, 12(2), 57-70, DOI: 10.4467/2353737XCT.19.021.1 0157.

Pilarczyk, A. \& Nowak, P. 2019. Factors Determining the Ways for Shaping the Landscapes of Municipal Cemeteries in Szczecin: Proposals of Changes in the Shaping of Municipal Cemeteries. IOP Conf. Ser. Mater. Sci. Eng., 471, 1-9, DOI: 10.1088/1757899X/471/9/092057.
Przybylska, L. 2014. Sakralizacja przestrzeni publicznych w Polsce (Sacralisation of public spaces in Poland), Wydawnictwo Uniwersytetu Gdańskiego, Gdańsk.

Rosiek, S. 2011. Cemetery and the Idea of (in)Equality [in:] Borzyszkowski, J. (eds.) Nekropolie Pomorza, Gdańsk, pp. 60-75.

Rozmarynowska, K. 2011. Garden-Cemetery in the 19th and 2-th Century Town Planning [in:] Borzyszkowski, J. (eds.) Nekropolie Pomorza, Gdańsk, pp. 175-206.

Rozmarynowska, K. 2017. Ogrody odchodzące...? Z dziejów gdańskiej zieleni publicznej 1708-1945 (Disappearig gardens...? The history of public green spaces in Gdańsk 1708-1945), Fundacja Terytoria Książki, Gdańsk.

Rudkowski, T. 2004. For the protection of historical cemeteries. Ochrona Zabytków, 1/2, 104-114.

Rugg, J. 2000. Defining the place of burial: what makes a cemetery a cemetery?. Mortality, 5(3), 259-275, DOI: 10.1080/713686011.

Rugg, J., \& Parsons, B. 2018. Funerary Practices in England and Wales, Bingly, Emerald Publishing.

Rydzewska, A., Krzyżaniak, M. \& Urbański, P. 2011. Niegdyśsacrum,dziś profanum-dawnecmentarze ewangelickie Poznania i okolic (Once sacred, profane today - the farmer evangelic cemeteries of the city of Poznan and the surrounding area). Prace Komisji Krajobrazu Kulturowego, 15, 64-72.

Skórzyńska, l., \& Wachowiak, A. 2016. Lokalne polityki pamięci zmarłych. "Cmentarze nieistniejących cmentarzy" w Gdańsku i Wrocławiu (Local policies on commemorating the dead. "Cemeteries of Non-existing Cemeteries" in Gdańsk and Wrocław.), Instytut Historii UAM, Poznań. 
Stępa, M. 1993. Przestrzenne aspekty kremacji (Spatial aspects of cremation). PhD Thesis, Gdańsk University of Technology, Gdańsk.

Studium uwarunkowań i kierunków zagospodarowania przestrzennego miasta Gdańska (Study of conditions and development directions of the city of Gdańsk), 2019. Biuro Rozwoju Gdańska, Gdańsk.

Studium uwarunkowań i kierunków zagospodarowania przestrzennego miasta Gdańska (Study of conditions and development directions of the city of Gdańsk), 2007. Biuro Rozwoju Gdańska, Gdańsk.

Swensen, G. 2018. Between romantic historic landscapes, rational management models and obliterations - urban cemeteries as green memory sites. Urban Forestry \& Urban Greening, 33, 58-65, DOI: 10.1016/j.ufug.2018.04.013.

Swensen, G., \& Skår, M. 2019. Urban cemeteries' potential as sites for cultural encounters. Mortality, 24:3, 333-356, DOI: 10.1080/13576275.2018.1461818.

Swensen, G., Nordh, H., \& Brendalsmo, J. 2016. A green space between life and death - a case study of activities in Gamlebyen Cemetery in Oslo, Norway. Norsk Geografisk Tidsskrift Norwegian Journal of Geography, 70(1), 41-53, DOI: 10.1080/00291951.2015.1102169.

Szczepański, J., \& Samól, P. 2011. The Migration of Gdańsk's Cemeteries. The Changes of the Burial Places in the City from the Middle Ages till Today [in:] Borzyszkowski, J. (eds.) Nekropolie Pomorza, Gdańsk, pp. 227-244.

Tanaś, S. 2004. The cemetery as a part of the geography of tourism, Turyzm, z. 14/2, 71-87.
Tenenbaum-Kulig, M. 2015. Użycie terenu cmentarnego na inny cel według ustawy z 31 stycznia 1959 r. o cmentarzach i chowaniu zmarłych (Changing the primary function of burial areas in the light of the Act of 31 January 1959 on Cemeteries and Burial of the Deceased) [in:] Gołaczyński, J., Mazurkiewicz, J., Turłukowski, J., \& Karkut D. (eds.), Non omnismoriar: osobiste i majątkowe aspekty prawne śmierci człowieka: zagadnienia wybrane, Uniwersytet Wrocławski. Wydział Prawa, Administracji i Ekonomii, Wrocław, pp. 772-793.

Tisler, B., \& Turzyński, M. 2012. Analiza programowo-przestrzenna potrzeb terenowych na miejsca cmentarne dla mieszkańców Gdańska (Programme-spatial analysis of demand for burial areas in Gdańsk), Biuro Rozwoju Gdańska, Gdańsk.

Tisler, B., \& Turzyński, M. 2019. Analiza programowoprzestrzenna potrzeb terenowych na miejsca cmentarne dla mieszkańców Gdańska aktualizacja (Updated programme-spatial analysis of demand for burial areas in Gdańsk), Biuro Rozwoju Gdańska, Gdańsk.

Tölle, A. 2008. Gdańsk. Cities, 25(2), 107-119, DOI: 10.1016/j.cities.2007.11.003.

Tomašević, A. 2018. Cemeteries as tourist attraction. Tourističko Poslovanje, 21, 13-24, DOI: 10.5937/ TurPos1821013T.

Tudor, C. A., lojă, I. C., Hersperger, A., \& Pătru-Stupariu, I. 2013. Is the residential land use incompatible with cemeteries location? Assessing the attitudes of urban residents. Carpathian Journal of Earth and Environmental Sciences, 8(2), 153-162.

Urbain, J. D. 2011. Semantics of Cemetery. Prolegomena to the Comparative Semiotics of the Places (and Non-Places) of the Deceased [in:] Borzyszkowski, J. (eds.) Nekropolie Pomorza, Gdańsk, pp. 27-40. 
Uslu, A., Bariş, E., \& Erdoğan, E. 2009. Ecological concerns over cemeteries. African Journal of Agricultural Research, 4(13), 1505-1511, DOI: 10.5897/AJAR.9000184.

Uslu, A. 2010. An ecological approach for the evaluation of an abandoned cemetery as a green area: The case of Ankara/Karakusunlar cemetery. African Journal of Agricultural Research, 5(10), 1043-1054, DOI: 10.5897/AJAR.9000041.

Vovelle, M. 2008. Śmierć w cywilizacji Zachodu: od roku 1300 po współczesność (Death in the civilisation of the West: from 1300 till the present times), Wydawnictwo słowo/obraz terytoria, Gdańsk.

Wacław, A. 2011. Revitalization Problems of Historical Cemeteries on the Example of the Garrison Cemetery in Gdańsk. Opportunities and Threats [in:] Borzyszkowski, J. (eds.) Nekropolie Pomorza, Gdańsk, pp. 355-369.

Wingren, C. 2013. Place-making strategies in multicultural Swedish cemeteries: the cases of 'Östra kyrkogården'in Malmö and Järva common. Mortality, 18(2), 151-172, DOI: 10.1080/13576275.2013.791265.

Yarwood, R., Sidaway, J. D., Kelly, C., \& Stillwell, S. 2015. Sustainable deathstyles? The geography of green burials in Britain, Geographical Journal, 181, 172-184, DOI: 10.1111/geoj.12087.

Young, C., \& Light, D. 2016. Interrogating spaces of and for the dead as 'alternative space': cemeteries, corpses and sites of Dark Tourism, International Review of Social Research, 6(2), 6172, DOI: 10.1515/irsr-2016-0009.
Zawiła, M. 2019. Dziedziczynienie przedwojennych cmentarzy na terenach postmigracyjnych Polski (Inheriting and perception of the pre-war cemeteries in the post-migration areas of Poland), Wydawnictwo Uniwersytetu Jagiellońskiego, Kraków.

Żurkowska, T. 2009. Mazurskie cmentarze. Symbole w krajobrazie (Masurian cemeteries. Symbols in the landscape), Borussia, Olsztyn. 